\title{
Detection of Zinc Ions by Differential Circularly Polarized Fluorescence Excitation
}

\author{
Zhaohua Dai, ${ }^{\dagger}$ Gloria Proni, ${ }^{\ddagger}$ Danny Mancheno ${ }^{\S}$, Sasan Karimi, ${ }^{\S}$ Nina Berova, \\ and James W. Canary*,$\dagger$ \\ ${ }^{\dagger}$ Department of Chemistry, New York University, New York, NY 10003, ${ }^{\dagger}$ Department of \\ Chemistry, Columbia University, New York, NY, 10027 and ${ }^{\S}$ Queensboro Community \\ College, CUNY, Bayside, NY 11364 \\ james.canary@nyu.edu
}

Table of Contents:

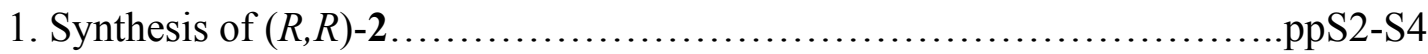

2. Fluorescence polarization ..............................................

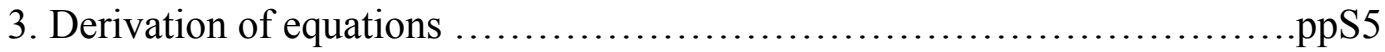

4. Spectroscopic measurements details...................................ppS6

5. Fluorescence, $\mathrm{CD}, \mathrm{UV}, \Delta \mathrm{F}, \mathrm{F}_{\mathrm{L}}+\mathrm{F}_{\mathrm{R}}$, converted FDCD

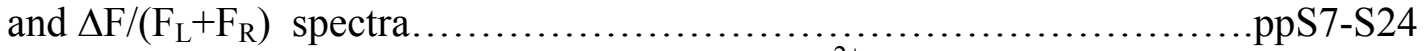

I. Figures 1e-1g: $(S, S)-\mathbf{2}$ responses to $\mathrm{Zn}^{2+}$ in acetonitrile

II. Figures 3a-3g: $(R, R)-\mathbf{1}$ responses to $\mathrm{Zn}^{2+}$ in acetonitrile ppS7-S8 aqueous solution.

III. Figures $4 \mathrm{a}-4 \mathrm{~g}:(R, R)-2$ responses to $\mathrm{Zn}^{2+}$ in $60 \%$ acetonitrile aqueous

IV. Figures 5a-5c: HEW lysozyme responses to $\mathrm{Zn}^{2+}$ in $60 \%$ acetonitrile/aqueous solution.........................ppS17-S18

V. Figures 6a-6d: $(R, R)-1$ responses to $\mathrm{Zn}^{2+}$ in $60 \%$ acetonitrile/ aqueous solution at the presence of $1.0 \mathrm{mg} / \mathrm{ml} \mathrm{lysozyme.........ppS19-S20}$

VI. Figure 7a-7c: Responses of $(S, S)-2$ to $\mathrm{Cu}^{2+}$ in acetonitrile........ppS21-S22

VII. Figure 8a-8c: Responses of $(R, R)-\mathbf{1}$ to $\mathrm{Cu}^{2+}$ in acetonitrile.........ppS23-S24

VIII. Figure 9: $\Delta \mathrm{F}$ response of $5 \mu \mathrm{M}(S, S)-1$ to $\mathrm{Zn}(\mathrm{II})$ and $\mathrm{Cu}(\mathrm{II})$ in acetonitrile. ppS24 


\section{Synthesis of $(R, R)-2$ :}

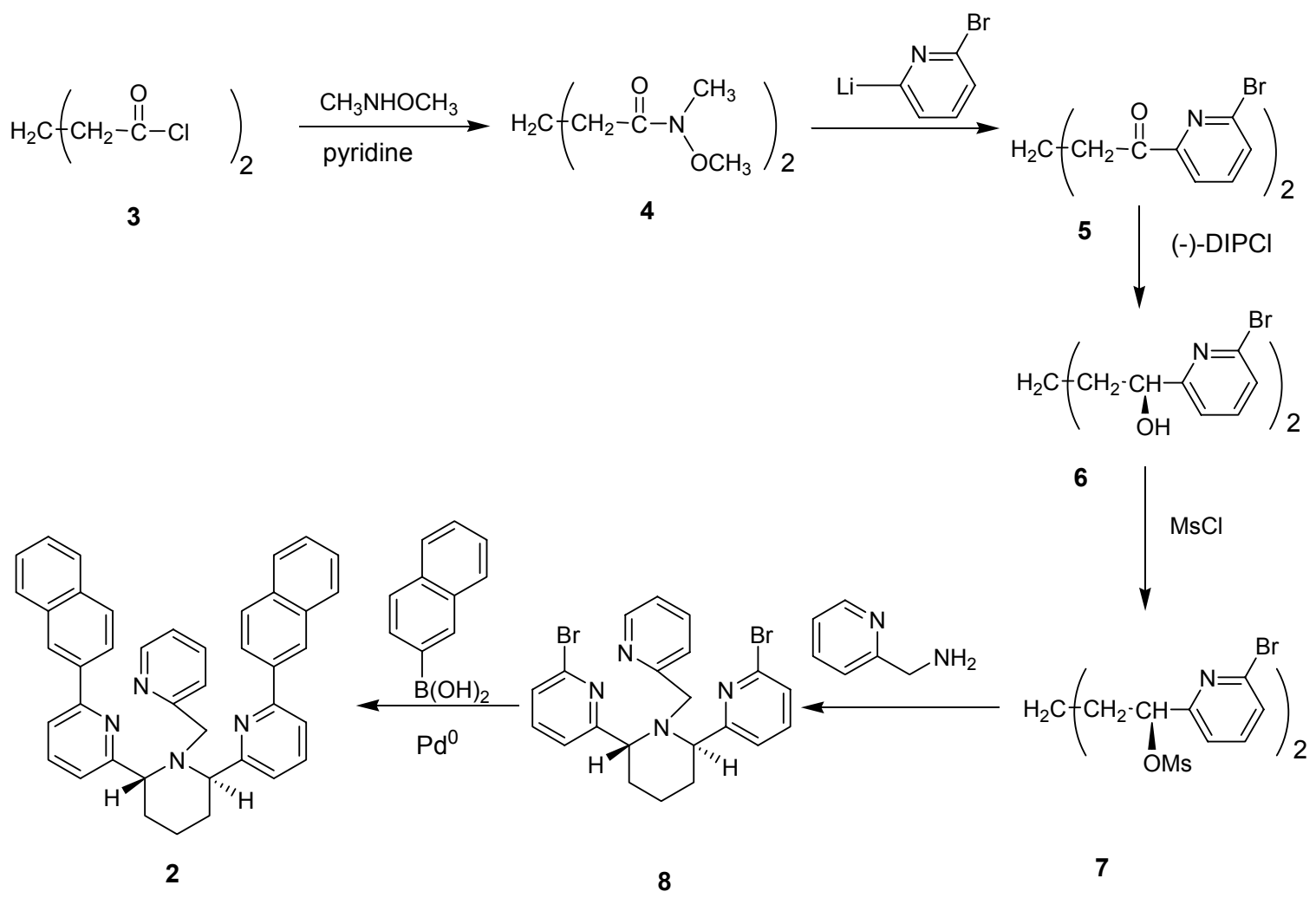

Scheme 2: Synthesis of compound $(R, R)-\mathbf{2}$

N-Methoxy-N-methylglutamide (4). Glutaryl dichloride (3) (1.69 g, $10 \mathrm{mmol}$ ) and N,Odimethylhydroxylamine hydrochloride $(2.15 \mathrm{~g}, 22 \mathrm{mmol})$ were put into $100 \mathrm{~mL}$ ethanol free chloroform. The mixture was chilled to $0^{\circ} \mathrm{C}$ and dry pyridine $(7.1 \mathrm{~mL}, 88 \mathrm{mmol})$ was added dropwise. The reaction mixture was stirred for 3 hours at room temperature. Then solvent was removed under reduced pressure. The residue was partitioned between brine and 1:1 ratio of diethyl ether: methylene chloride. The organic layer was collected and dried over $\mathrm{MgSO}_{4}$. Removal of the solvent gave $2.17 \mathrm{~g}$ compound 4, which was carried to the next step without further purification. ${ }^{1} \mathrm{HNMR}\left(200 \mathrm{MHz}, \mathrm{CDCl}_{3}\right) \delta 3.64(\mathrm{~s}, 6 \mathrm{H})$, $3.12(\mathrm{~s}, 6 \mathrm{H}), 2.48(\mathrm{t}, \mathrm{J}=7.1 \mathrm{~Hz}, 4 \mathrm{H}), 1.93(\mathrm{p}, \mathrm{J}=7.1 \mathrm{~Hz}, 2 \mathrm{H}) .{ }^{13} \mathrm{CNMR}\left(50 \mathrm{MHz}, \mathrm{CDCl}_{3}\right) \delta$ $176.6,61.7,32.8,31.7,20.1$.

1,5-Di(6-bromo-2-pyridyl)pentane-1,5-dione (5). The compound 2,6-dibromopridine $(26.23 \mathrm{~g}, 110.7 \mathrm{mmol})$ was dissolved in $200 \mathrm{ml}$ dry diethyl ether under dry nitrogen. The solution was chilled to $-78^{\circ} \mathrm{C}$ and $1.6 \mathrm{M} \mathrm{n}$-BuLi $(69.2 \mathrm{~mL}, 110.7 \mathrm{mmol})$ was added dropwise. The solution was stirred for $30 \mathrm{~min}$ and compound $4(10.97 \mathrm{~g}, 50.3 \mathrm{mmol})$ in $20 \mathrm{~mL}$ dry diethyl ether was added dropwise. The solution was stirred at this temperature for $2 \mathrm{~h}$ and slowly warmed to room temperature and stirred overnight. Then $5 \% \mathrm{HCl}$ was added and the solution was extracted with three portions of $100 \mathrm{~mL}$ diethyl ether. The ether layers were combined and dried over $\mathrm{MgSO}_{4}$. Then solvent was evaporated under 
reduced pressure. The pure compound $5(15.36 \mathrm{~g})$ was obtained by recrystallizing the crude product from petroleum ether in $74 \%$ yield. ${ }^{1} \mathrm{HNMR}\left(200 \mathrm{MHz}, \mathrm{CDCl}_{3}\right) \delta 7.97-$ $8.01(\mathrm{~m}, 2 \mathrm{H}), 3.32(\mathrm{t}, \mathrm{J}=7.2 \mathrm{~Hz}, 4 \mathrm{H}), 2.16$ (p, J=7.2 Hz, 2H). ${ }^{13} \mathrm{CNMR}\left(50 \mathrm{MHz}, \mathrm{CDCl}_{3}\right)$ $\delta$ 200.2, 154.5, 141.8, 139.6, 132.2, 121.0, 37.5, 18.4. MS (MALDI-TOF): Calcd (m/e): 412.1, Found: $412.9\left(\mathrm{M}+\mathrm{H}^{+}\right)$. Elemental Anal.(mass \%): Calcd C, 43.72: H, 2.94; N, 6.80. Found: C, 43.87; H, 2.85; N, 6.61 .

1,5-Di(6-bromo-2-pyridyl)pentane-(1S,5S)-diol (6). Compound 5 (8.85 g, 21.47 mmol) and (-)-DIP-Cl (15.15 g, $47.23 \mathrm{mmol})$ were mixed together and $100 \mathrm{~mL}$ anhydrous THF was added under dry nitrogen. The solution was stirred at $-78^{\circ} \mathrm{C}$ for $2 \mathrm{~h}$ and slowly warmed up to room temperature and stirred overnight. After addition of $5 \% \mathrm{HCl}$ the solution was stirred for one more hour. The resulting solution was extracted with three portions of $100 \mathrm{~mL}$ methylene chloride and the organic layers were combined and dried over $\mathrm{MgSO}_{4}$. Then solvent was removed and the crude product was purified by flash chromatography to give the desire compound 6 in $64 \%$ yield $(5.7 \mathrm{~g})$ as a white solid. ${ }^{1} \mathrm{HNMR}\left(200 \mathrm{MHz}, \mathrm{CDCl}_{3}\right) \delta 7.54(\mathrm{t}, \mathrm{J}=7.6 \mathrm{~Hz}, 2 \mathrm{H}), 7.37$ (d, J=7.6 Hz, 2H), 7.26 (d, J $=7.6 \mathrm{~Hz}, 2 \mathrm{H}), 4.68-4.76(\mathrm{~m}, 2 \mathrm{H}), 3.45-3.48(\mathrm{~m}, 2 \mathrm{H}), 1.53-1.90(\mathrm{~m}, 6 \mathrm{H}) .{ }^{13} \mathrm{CNMR}(50$ $\left.\mathrm{MHz}_{\mathrm{CDCl}}\right) \delta 164.8,141.6,139.5,127.0,119.5,73.4,38.5,21.8$. MS (MALDI-TOF): Calcd (m/e): 416.1, Found: $416.8\left(\mathrm{M}+\mathrm{H}^{+}\right)$. Elemental Anal.(mass \%): Calcd C, 43.30; H, 3.88 ; N, 6.73. Found: C, 43.59; H, 3.95; N, 6.67.

1,5-Di(6-bromo-2-pyridyl)-(1S,5S)-di(methylsulfonyl)pentane (7). $\mathrm{MsCl}$ (1.07 g, 9.38 mmol) was dissolved in $30 \mathrm{~mL}$ dry methylene chloride at $-20^{\circ} \mathrm{C}$. To this solution was added compound $6(1.5 \mathrm{~g}, 3.61 \mathrm{mmol})$ and triethylamine $(1.55 \mathrm{~mL}, 11.13 \mathrm{mmmol})$ in 30 $\mathrm{mL}$ methylene chloride. The solution was stirred for $3 \mathrm{~h}$ and then water was added. The mixture was extracted was three portions of $30 \mathrm{~mL}$ methylene chloride. The organic layers were combined and dried over sodium sulfate. Solvent was removed under reduced pressure. Recrystyllization of the crude product from ethyl acetate gave $1.72 \mathrm{~g}$ of the desired compound 7 in $82 \%$ yield. ${ }^{1} \mathrm{HNMR}\left(200 \mathrm{MHz}, \mathrm{CDCl}_{3}\right) \delta(\mathrm{ppm}) 7.62(\mathrm{t}, \mathrm{J}=7.6 \mathrm{~Hz}$, 2H), $7.46(\mathrm{~d}, \mathrm{~J}=7.6 \mathrm{~Hz}, 2 \mathrm{H}), 7.43$ (d, J=7.6 Hz, 2H), $5.58(\mathrm{t}, \mathrm{J}=6.8 \mathrm{~Hz}, 2 \mathrm{H}, 3.01(\mathrm{~s}, 6 \mathrm{H})$, 2.03-2.12 (m, 4H), 1.53-1.66 (m, 2H). ${ }^{13} \mathrm{CNMR}\left(50 \mathrm{MHz}, \mathrm{CDCl}_{3}\right) \delta(\mathrm{ppm}) 159.5,153.2$, 139.9, 128.5, 120.3, 82.5, 39.2, 35.0, 21.2. Elemental Anal.(mass \%): Calcd C, 35.68; H, $3.52 ; \mathrm{N}, 4.89$. Found: C, 35.47; H, 3.28; N, 4.71.

1-(2-Pyridylmethyl)-(2R, 6R)-di(6-bromo-2-pyridyl)piperidine (8). Compound 7 (926 $\mathrm{mg}, 1.62 \mathrm{mmol})$ and 2-(aminomethyl)-pyridine $(5.25 \mathrm{~g}, 48.47 \mathrm{mmol})$ were mixed together under nitrogen. The solution was stirred at $70^{\circ} \mathrm{C}$ overnight. The excess 2(aminomethyl)-pyridine was removed by vacuum distillation. The residue was subjected to column chromatography to give $476 \mathrm{mg}$ compound $\mathbf{8}$ in $60.3 \%$ yield. Chiral HPLC analysis indicates the ee is $>99 \%$. ${ }^{1} \mathrm{HNMR}\left(200 \mathrm{MHz}, \mathrm{CDCl}_{3}\right) \delta(\mathrm{ppm}) 8.40(\mathrm{~d}, \mathrm{~J}=4.5 \mathrm{~Hz}$, $1 \mathrm{H}), 7.57-7.66(\mathrm{~m}, 1 \mathrm{H}), 7.43-7.51(\mathrm{~m}, 5 \mathrm{H}), 7.25-7.33(\mathrm{~m}, 2 \mathrm{H}), 7.04-7.10(\mathrm{~m}, 1 \mathrm{H}), 4.44$ $(\mathrm{dd}, \mathrm{J}=6.4,4.5 \mathrm{~Hz}, 2 \mathrm{H}), 3.79\left(\mathrm{~d}, \mathrm{~J}_{\mathrm{gem}}=15.8 \mathrm{~Hz}, 1 \mathrm{H}\right), 3.64\left(\mathrm{~d}, \mathrm{~J}_{\mathrm{gem}}=15.8 \mathrm{~Hz}, 1 \mathrm{H}\right), 1.67-2.19$ $(\mathrm{m}, 6 \mathrm{H}) .{ }^{13} \mathrm{CNMR}\left(50 \mathrm{MHz}, \mathrm{CDCl}_{3}\right) \delta(\mathrm{ppm}) 165.9,160.7,149.4,141.8,139.0,136.8$, 126.5, 122.7, 122.1, 121.9, 61.9, 56.6, 30.3, 19.3. MS (MALDI-TOF): Calcd (m/e): 488.2, Found: $489.2\left(\mathrm{M}+\mathrm{H}^{+}\right)$. Elemental Anal.(mass \%): Calcd C, 51.64: H, 4.10; N, 11.27. Found: C, 51.83; H, 4.38; N, 11.26.

1-(2-Pyridylmethyl)-(2R, 6R)-di(6-bromo-2-pyridyl)piperidine (2). To a solution of compound $8(220 \mathrm{mg}, 0.45 \mathrm{mmol})$ and $\mathrm{Pd}\left(\mathrm{PPh}_{3}\right)_{4}(100 \mathrm{mg})$ in $3 \mathrm{~mL}$ of toluene and $3 \mathrm{~mL}$ of $2 \mathrm{M}$ aqueous sodium carbonate was added 2-naphthalene boronic acid (232 mg) in $2 \mathrm{~mL}$ 
methanol. The solution was heated to $80^{\circ} \mathrm{C}$ for $3 \mathrm{~h}$ and stirred at $70^{\circ} \mathrm{C}$ overnight. After the reaction mixture was cooled, $5 \% \mathrm{HCl}$ was added and stirring was continued for an additional hour. The suspension was vacuum filtered, and the solid extract on the filter paper was treated with $6 \mathrm{M} \mathrm{NaOH}(20 \mathrm{~mL})$ and then extracted with methylene chloride $(50 \mathrm{~mL})$ and ether $(20 \mathrm{~mL})$. The organic layer was dried and solvent was removed to give a crude yellow oil $(0.18 \mathrm{~g}, 70 \%)$. The crude oil was purified by a Chromatotron (radial chromatography) with $2 \%$ methanol in ethyl acetate as eluent to afford the pure compound $2(0.14 \mathrm{~g})$ in $54 \%$ yield. ${ }^{1} \mathrm{HNMR}\left(200 \mathrm{MH}_{\mathrm{Z}}, \mathrm{CDCl} 3\right) \delta(\mathrm{ppm}) 8.60(\mathrm{~d}, \mathrm{~J}=1.1 \mathrm{~Hz}$, 2H), 8.42(dt, J=1.7, $4.7 \mathrm{~Hz}, 1 \mathrm{H}), 8.31(\mathrm{dd}, \mathrm{J}=1.7,8.6 \mathrm{~Hz}, 2 \mathrm{H}), 7.96(\mathrm{~d}, \mathrm{~J}=8.8 \mathrm{~Hz}, 4 \mathrm{H})$, 7.87(m, 2H), 7.75(d, J=4.9 Hz, 4H), 7.48-7.68 (m, 8H), $7.06(\mathrm{~m}, 1 \mathrm{H}), 4.79(\mathrm{dd}, \mathrm{J}=5.0,6.2$ $\mathrm{Hz}, 2 \mathrm{H}), 4.06\left(\mathrm{~d}, \mathrm{~J}_{\mathrm{gem}}=15.8 \mathrm{~Hz}, 1 \mathrm{H}\right), 3.93\left(\mathrm{~d}, \mathrm{~J}_{\mathrm{gem}}=15.8 \mathrm{~Hz}, 1 \mathrm{H}\right), 2.16-2.30(\mathrm{~m}, 4 \mathrm{H}), 1.96-$ $1.95(\mathrm{~m}, 2 \mathrm{H}){ }^{13} \mathrm{CNMR}(400 \mathrm{MHz}, \mathrm{CDCl} 3) \delta(\mathrm{ppm}): 163.9,161.3,155.9,148.8,139.8$, $137.1,137.0,136.2,133.6,133.5,128.8,128.3,127.6,126.3,126.2,126.1,124.9,122.2$, 121.4, 121.0, 118.2, 62.0, 56.0, 29.5, 19.8. MS (APCI): Calcd (m/e): 582.7, Found: $584.2\left(\mathrm{M}+\mathrm{H}^{+}\right)$. Elemental Anal.(mass \%): Calcd C, 84.50: H, 5.88; N, 9.61. Found: C, $84.24 ; \mathrm{H}, 5.75 ; \mathrm{N}, 9.58$.

\section{Fluorescence polarization}

Fluorescence polarization $\mathbf{P}$, the ratio of the difference between the intensity of the horizontally and vertically polarized emission components to the sum of the of these two components originating from a horizontally plane-polarized excitation, were measured on a Hitachi F-2500 Spectrophotometer with polarizers. Excitation was set at $280 \mathrm{~nm}$ and vertically and horizontally polarized emission components were observed at emission maxima. $\mathbf{P}$ was calculated according to the following formula:

$P=\frac{I_{/ /}-G * I_{\perp}}{I_{/ /}+G * I_{\perp}}$

$\mathrm{G}$ is an instrument factor and $G=\frac{i_{\perp}}{i_{/ /}}$, which is the ratio of the intensity of the vertically to the horizontally polarized emission components originating from a vertically planepolarized excitation.

Fluorescence polarization values are compiled in the following table (next page).

\begin{tabular}{|c|c|c|c|c|}
\hline & \multicolumn{2}{|c|}{$\mathrm{CH}_{3} \mathrm{CN}$} & \multicolumn{2}{c|}{$15 \% \mathrm{CH}_{3} \mathrm{CN} / \mathrm{H}_{2} \mathrm{O}$} \\
\hline & $\lambda_{\max }$ & $\mathbf{P}$ & $\lambda_{\max }$ & $\mathbf{P}$ \\
\hline$(\mathrm{R}, \mathrm{R})-\mathbf{1}$ & 371 & 0.029 & 385 & 0.012 \\
\hline$(\mathrm{R}, \mathrm{R})-\mathbf{1}+\mathrm{Isz}$ & & & 361 & 0.043 \\
\hline$(\mathrm{R}, \mathrm{R})-\mathbf{1}-\mathrm{Zn}$ & 393 & -0.0065 & 399 & 0.017 \\
\hline$(\mathrm{R}, \mathrm{R})-\mathbf{1 - Z n}+\mathrm{Isz}$ & & & 393 & 0.026 \\
\hline$(\mathrm{R}, \mathrm{R})-\mathbf{2}$ & 363 & -0.011 & 370 & 0.0079 \\
\hline$(\mathrm{R}, \mathrm{R})-\mathbf{2}+\mathrm{Isz}$ & & & 365 & -0.022 \\
\hline$(\mathrm{R}, \mathrm{R})-\mathbf{2}-\mathrm{Zn}$ & 400 & -0.0038 & 391 & 0.0093 \\
\hline$(\mathrm{R}, \mathrm{R})-2-\mathrm{Zn}+\mathrm{Isz}$ & & & 386 & -0.0075 \\
\hline
\end{tabular}

Note: lsz $=$ Hen egg white lysozyme 


\section{Derivation of equations:}

From classic FDCD conversion equations

$$
\begin{aligned}
& \Delta \varepsilon=\frac{2 \bullet\left(1-10^{-A}\right) \bullet S}{c d 10^{-A} \ln 10} \\
& \theta=\left[33 \bullet 2 \bullet\left(10^{A}-1\right) \bullet S\right] / \ln 10 \\
& \text { and } S=k \bullet \frac{F_{L}-F_{R}}{F_{L}+F_{R}}=k \bullet \frac{\Delta F}{F_{L}+F_{R}}
\end{aligned}
$$

you get

$$
\Delta F=\frac{\theta \bullet\left(F_{L}+F_{R}\right) \bullet \ln 10}{33 \bullet 2 \bullet\left(10^{A}-1\right) \bullet k}
$$

Where $\mathrm{A}$ is the absorbance and $\mathrm{k}$ is a derived instrumental constant.

$$
\begin{aligned}
F & =\Phi\left(I^{0}-I\right)=\Phi I^{0}\left(1-\frac{I}{I^{0}}\right) \\
& =\Phi I^{0}\left(1-10^{-A}\right)
\end{aligned}
$$

If $\Delta \mathrm{A}=\mathrm{A}_{\mathrm{L}}-\mathrm{A}_{\mathrm{R}} \leq 0.1$ and $\Delta \mathrm{A} / \mathrm{A} \leq 0.1$, total emission $\left(\mathrm{F}_{\mathrm{L}}+\mathrm{F}_{\mathrm{R}}\right)$ should be proportional to fluorescence induced by non-polarized light, i.e., $\mathrm{F}_{\mathrm{L}}+\mathrm{F}_{\mathrm{R}}=\mathrm{k}_{2} \mathrm{~F}=\mathrm{k}_{2} \Phi \mathrm{I}^{0}\left(1-10^{-\mathrm{A}}\right)$. Then the equation can be simplified into equation (2), where $\mathrm{k}_{2}$ is another instrumental constant and $\Phi_{\mathrm{F}}$ is fluorescence quantum yield.

$$
\Delta F=\frac{\theta \bullet \Phi_{F} \bullet I^{0} \bullet k_{2} \bullet \ln 10}{33 \bullet 2 \bullet 10^{A} \bullet k}
$$

Consolidate all constants into $\mathrm{K}$, one get

$$
\Delta F=K \bullet \frac{\theta \bullet \Phi_{F} \bullet I^{0}}{10^{A}}
$$

If two samples of the same concentration are measured under the same experimental condition, the contrast between them can be expressed by equation 4 .

$$
\frac{\Delta F_{a}}{\Delta F_{b}}=\frac{\Phi_{a}}{\Phi_{b}} \bullet \frac{\theta_{a}}{\theta_{b}} \bullet \frac{10^{A_{b}}}{10^{A_{a}}}
$$

For two samples in which the differences in CD and fluorescence are dominant and UV difference is small, the UV contribution to contrast can be negligible. For example, changes of $\mathrm{A}$ in $0.3,0.2$ and 0.1 unit only result in change of the last factor $\frac{10^{A_{b}}}{10^{A_{a}}}$ (UV contribution) in $1.99,1.58$ and $1.28(0.50,0.63$ and 0.78$)$ respectively. So the contrast in $\Delta \mathrm{F}$ signal between a sample with both large quantum yield and large $\mathrm{CD}$ and a sample with both small quantum yield and $C D$ will be much bigger than that either in fluorescence or in CD signal. If monitored at a specific wavelength, the difference between two samples in fluorescence and $\mathrm{CD}$ properties can result in more striking difference in $\Delta \mathrm{F}$ signals. Even in one sample containing several different fluorescence 
and $\mathrm{CD}$ active species, it is still possible that only the $\Delta \mathrm{F}$ signal of only one species show up under optimized conditions. These serve to elevate contrast and reduce interferences.

\section{Spectroscopic measurements details:}

Fluorescence measurements were performed on a Hitachi F-2500 Spectrophotometer at NYU, CD spectra were measured on Aviv 201 at NYU and JASCO J-8100 spectrometer with J-405 attachment at Columbia, FDCD were measured on JASCO J-8100 with FDCD attachment at Columbia. In all measurements, $1 \mathrm{~cm}$ cells were used. Prior to measurements, all instruments were warmed for half an hour.

In FDCD measurements, a filter glass with cutoff at $360 \mathrm{~nm}$ was used so that all fluorescence contribution below $360 \mathrm{~nm}$ was not collected because FDCD scan started at $350 \mathrm{~nm}$ in these experiments. Slit width was set at $4 \mathrm{~nm}$. Appropriate sample concentration and electrical voltage were applied so that fluorescence signals were suitable for FDCD measurements (the DC channel: highest total fluorescence diode of the FDCD gave a maximum around $1.0 \mathrm{~V}$ ), and the voltage was kept constant during one titration experiment as were the rest of the conditions.

The concentration of stock solution of $\mathrm{Zn}\left(\mathrm{ClO}_{4}\right)_{2}$ or $\mathrm{Cu}\left(\mathrm{ClO}_{4}\right)_{2}$ was determined by titration with commercially acquired EDTA standard solution. The concentration of the stock solution of any other material was determined by weight and volume.

Supplementary spectra are shown in the following pages. 


\section{UV, Fluorescence, $\mathrm{CD}, \Delta \mathrm{F}$ spectra and other spectra}

\section{I. $(S, S)-2$ responses to $\mathrm{Zn}^{2+}$ in acetonitrile.}

Figure 1e. UV response of $2 \mu \mathrm{M}(S, S)-2$ to $0,0.4,0.8,1.2,1.6,2.0,2.4,2.8 \mu \mathrm{M} \mathrm{Zn}^{2+}$ in acetonitrile.

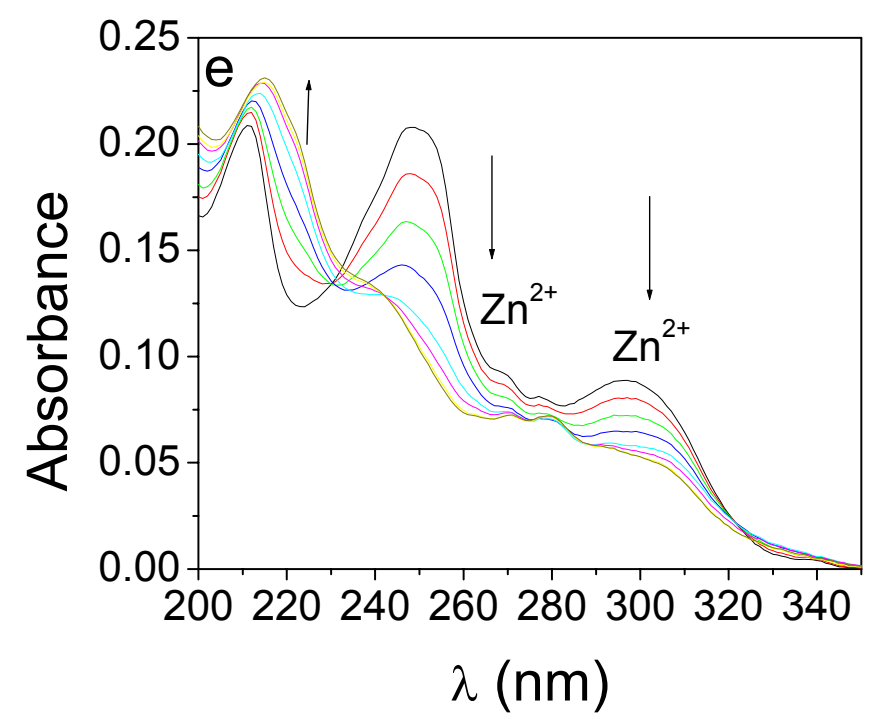

Figure 1f. $\left(\mathrm{F}_{\mathrm{L}}+\mathrm{F}_{\mathrm{R}}\right)$ response of $2 \mu \mathrm{M}(S, S)-2$ to $0,0.4,0.8,1.2,1.6,2.0,2.4,2.8 \mu \mathrm{M}$ $\mathrm{Zn}^{2+}$ in acetonitrile.

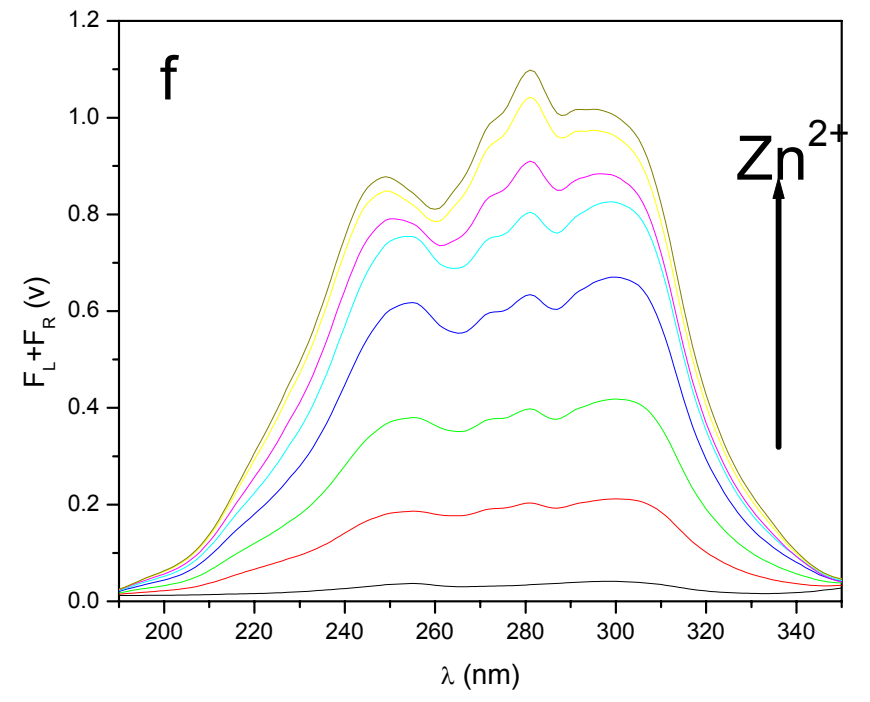


Figure 1g. $\Delta \mathrm{F} /\left(\mathrm{F}_{\mathrm{L}}+\mathrm{F}_{\mathrm{R}}\right)$ response of $2 \mu \mathrm{M}(S, S)-2$ to $0,0.4,0.8,1.2,1.6,2.0,2.4,2.8$ $\mu \mathrm{M} \mathrm{Zn}{ }^{2+}$ in acetonitrile.

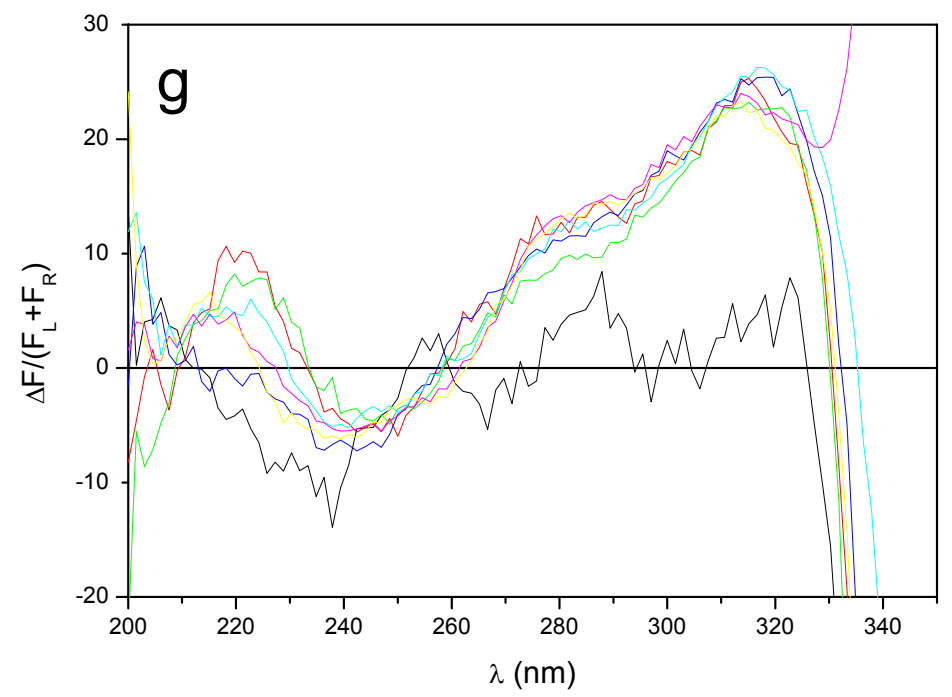




\section{Response of $(R, R)-1$ to $\mathrm{Zn}^{2+}$ in acetonitrile.}

Figure 3a. Fluorescence response of $4.8 \mu \mathrm{M}(R, R)-1$ to $0,0.4,0.8,1.2,1.6,2.0,2.4,2.8$,

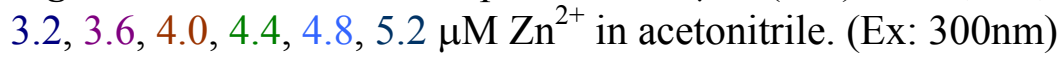

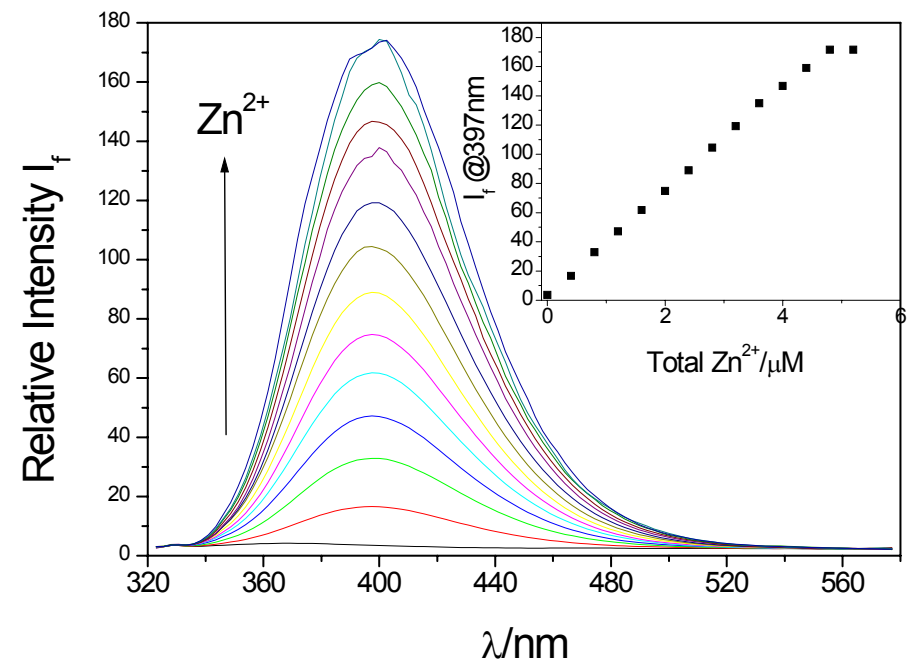

Figure $3 \boldsymbol{b}$. CD response of $4.8 \mu \mathrm{M}(R, R)-1$ to $0,0.4,0.8,1.2,1.6,2.0,2.4,2.8,3.2,3.6$,

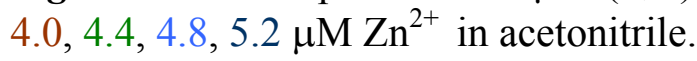

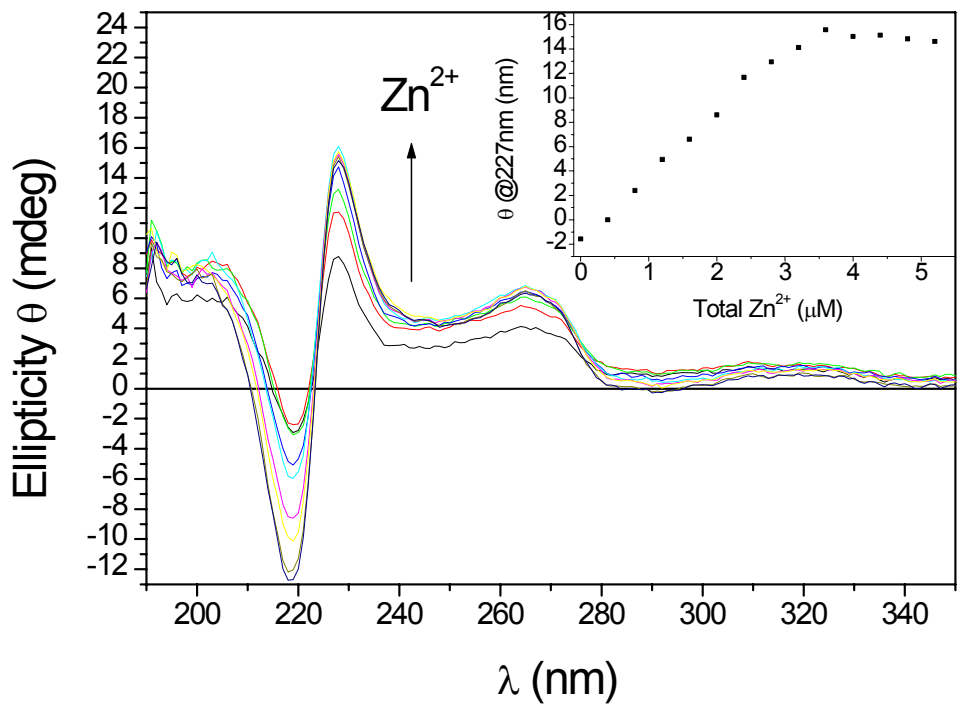


Figure $3 c$. UV response of $4.8 \mu \mathrm{M}(R, R)-1$ to $0,0.4,0.8,1.2,1.6,2.0,2.4,2.8,3.2,3.6$, $4.0,4.4,4.8,5.2 \mu \mathrm{M} \mathrm{Zn}^{2+}$ in acetonitrile.

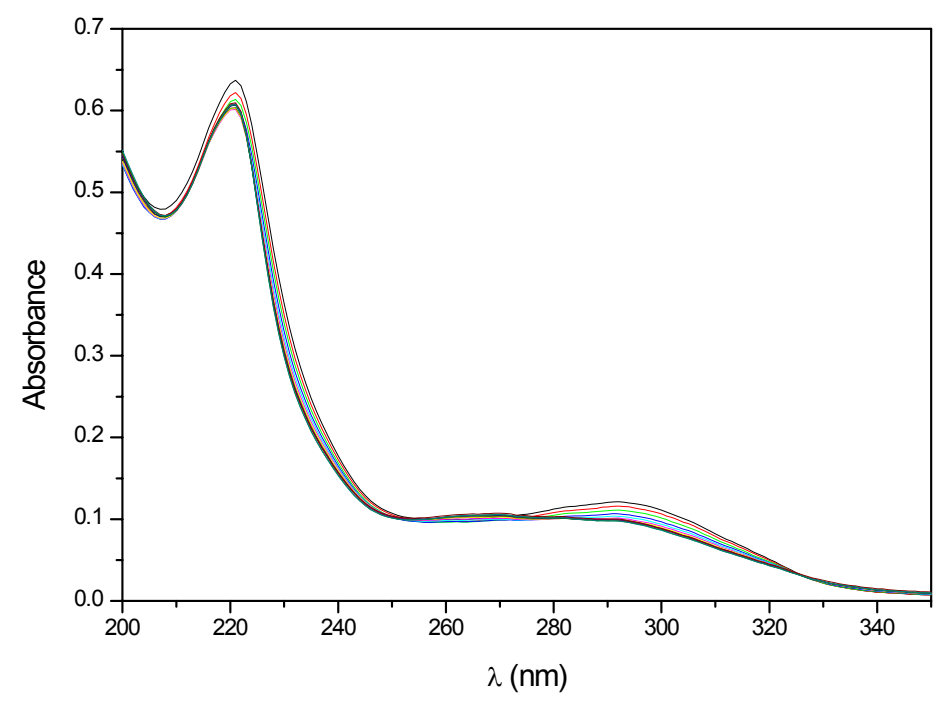

Figure 3d. $\Delta \mathrm{F}$ response of $4.8 \mu \mathrm{M}(R, R)-1$ to $0,0.4,0.8,1.2,1.6,2.0,2.8,3.2,3.6,4.0$, 4.4, 4.8, $5.2 \mu \mathrm{M} \mathrm{Zn}^{2+}$ in acetonitrile. (Fluorescence filter cutoff: $360 \mathrm{~nm}$, Voltage $700 \mathrm{~V}$, 81 degree.)

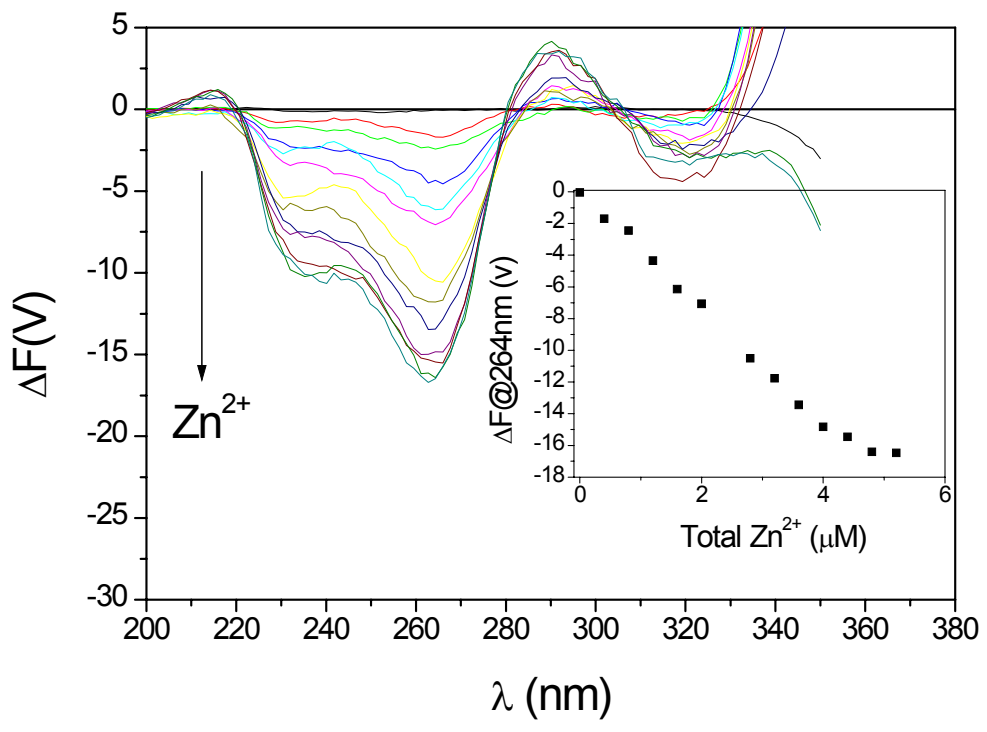


Figure 3e. $\left(\mathrm{F}_{\mathrm{L}}+\mathrm{F}_{\mathrm{R}}\right)$ response of $4.8 \mu \mathrm{M}(R, R)-1$ to $0,0.4,0.8,1.2,1.6,2.0,2.8,3.2,3.6$,

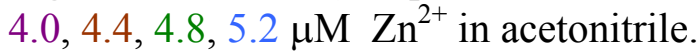

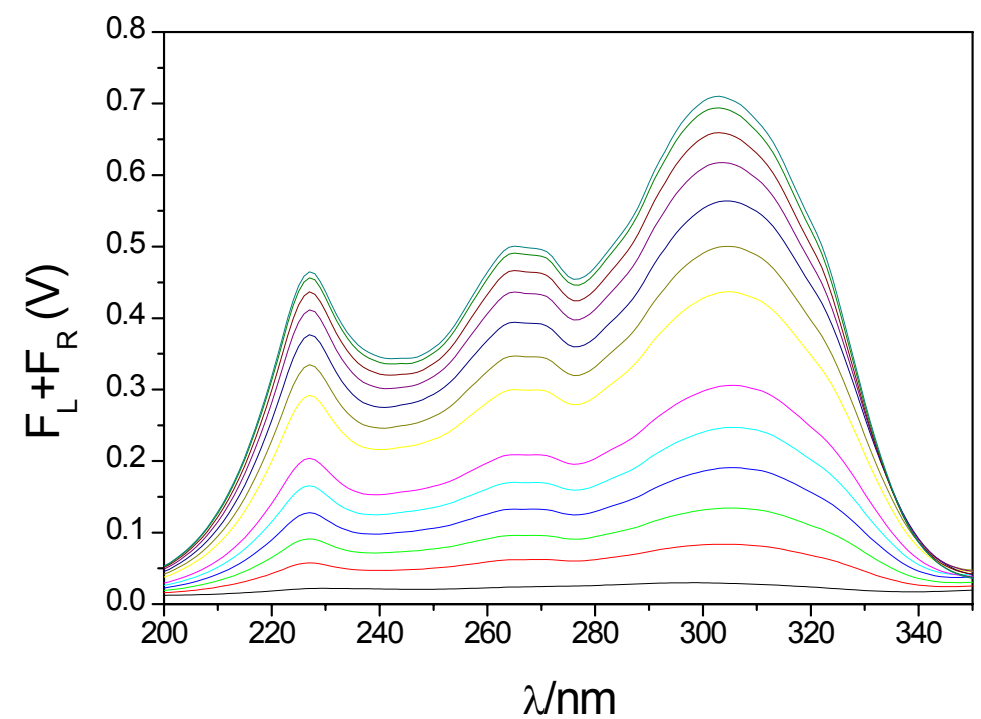

Figure 3f. Converted FDCD (to CD) response of $4.8 \mu \mathrm{M}(R, R)-1$ to $0,0.4,0.8,1.2,1.6$, $2.0,2.4,2.8,3.2,3.6,4.0,4.4,4.8,5.2 \mu \mathrm{M} \mathrm{Zn}^{2+}$ in acetonitrile.

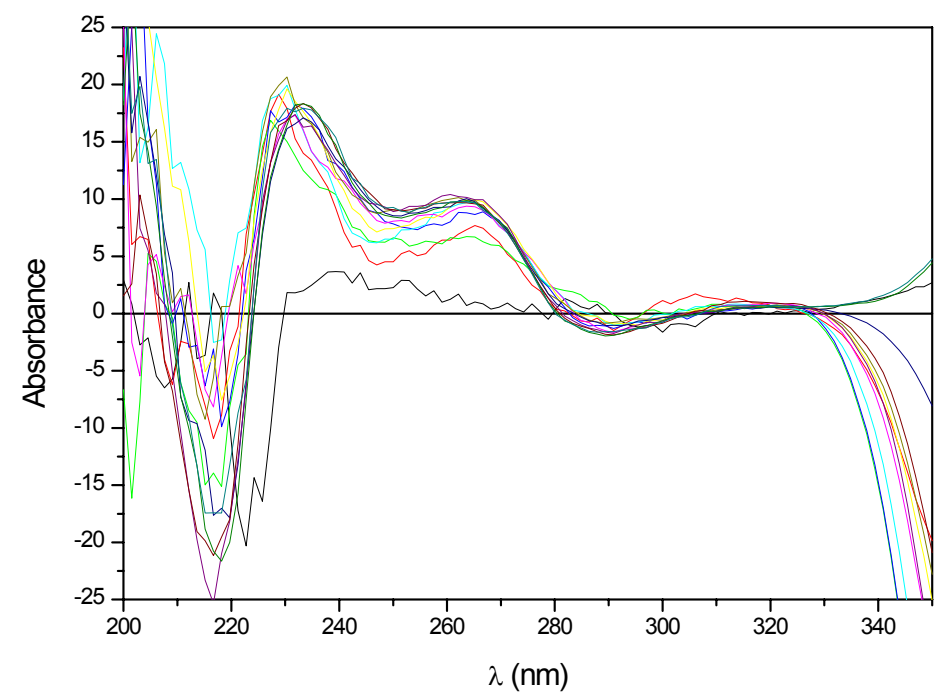


Figure 3g. $\Delta \mathrm{F} /\left(\mathrm{F}_{\mathrm{L}}+\mathrm{F}_{\mathrm{R}}\right)$ response of $4.8 \mu \mathrm{M}(R, R)-1$ to $0,0.4,0.8,1.2,1.6,2.0,2.8,3.2$,

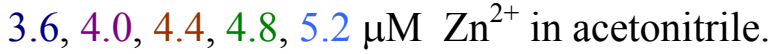

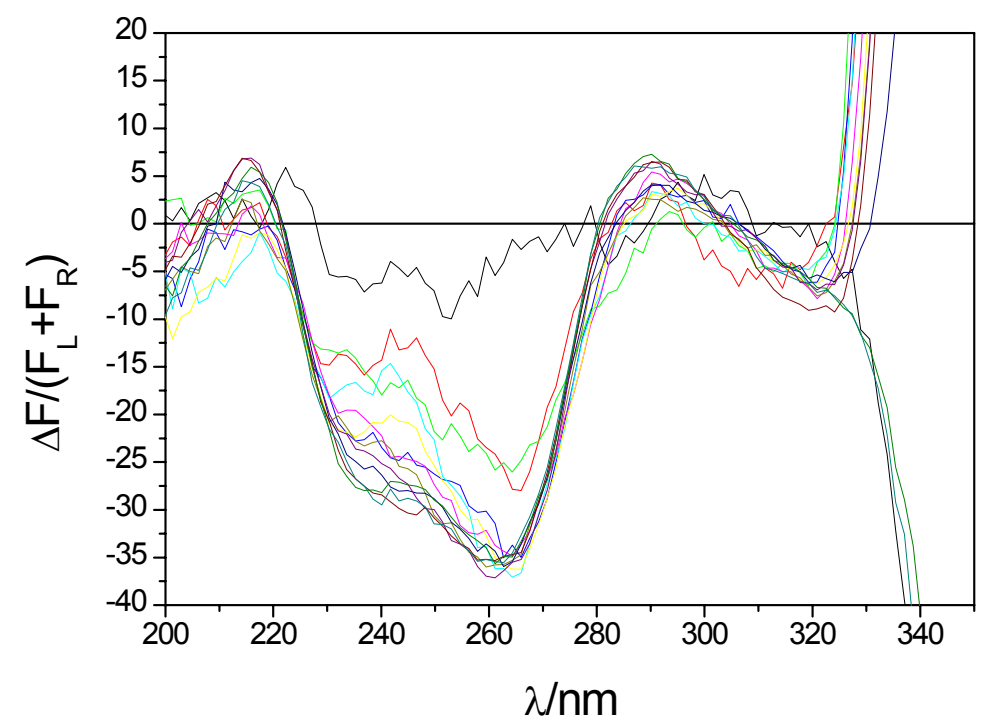




\section{III. $(R, R)-2$ responses to $\mathrm{Zn}^{2+}$ in $60 \%$ acetonitrile/aqueous solution}

Figure $4 a$. Fluorescence response of $3.2 \mu \mathrm{M}(R, R)-2$ to $\mathrm{Zn}^{2+}$ in $60 \%$ acetonitrile/aqueous solution (Ex: $280 \mathrm{~nm}$ ).

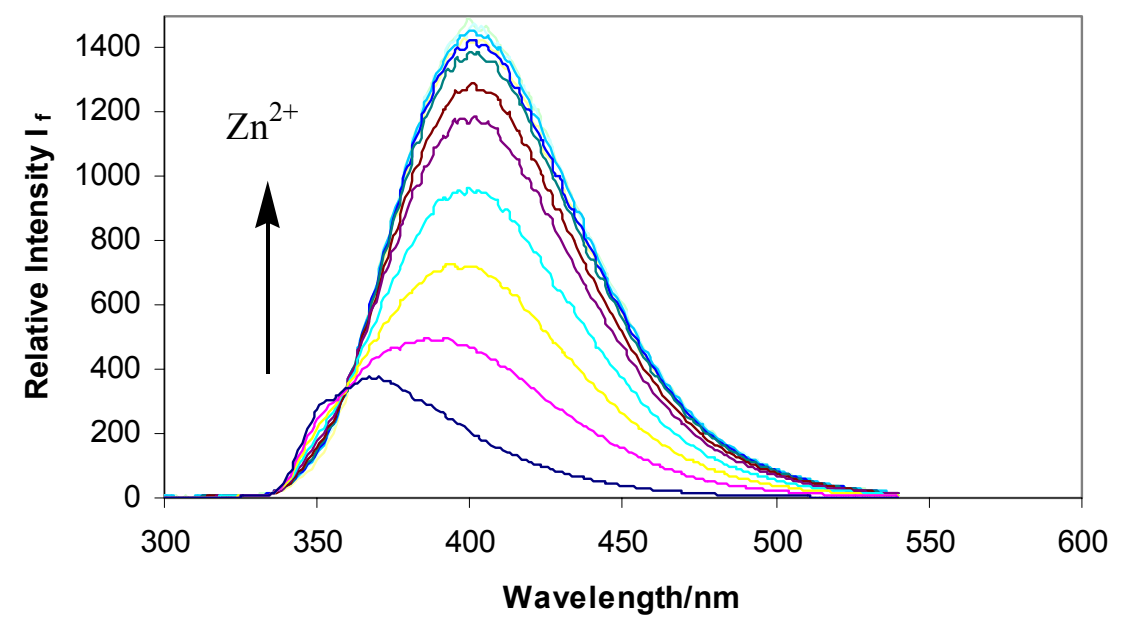

Figure 4 b. $\mathrm{CD}$ response of $3.2 \mu \mathrm{M}(R, R)-2$ to $\mathrm{Zn}^{2+}$ in $60 \%$ acetonitrile/aqueous solution.

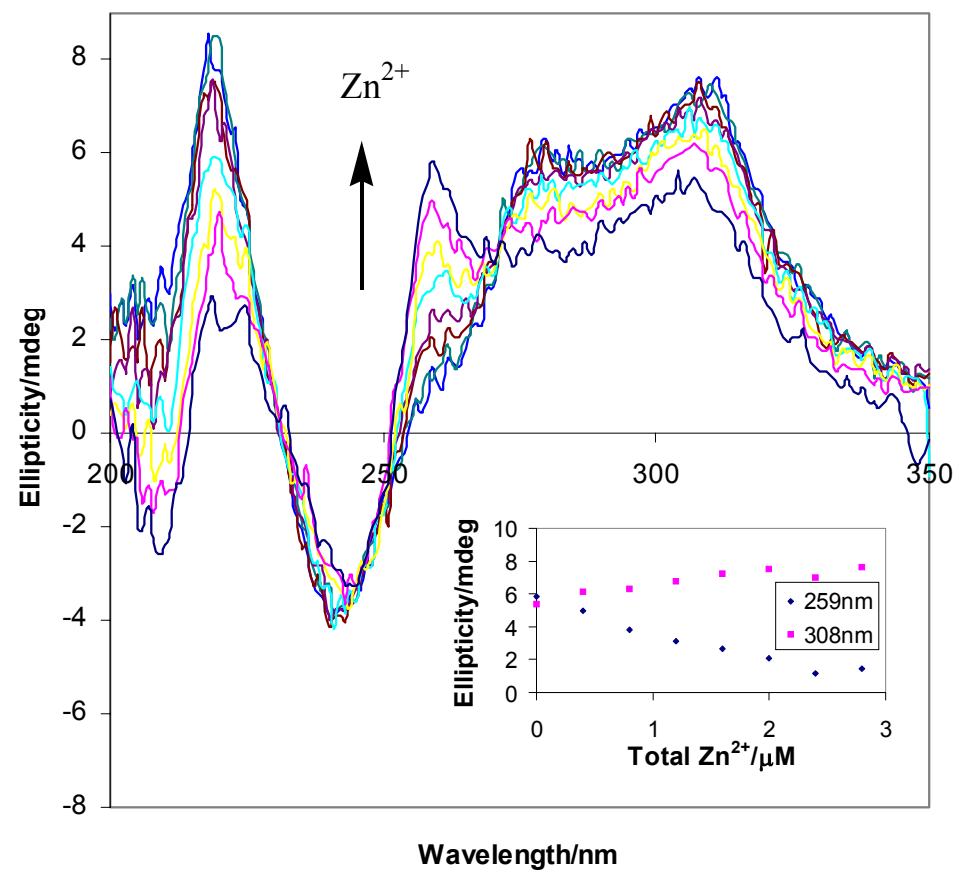


Figure $4 c . \Delta \mathrm{F}$ response of $3.2 \mu \mathrm{M}(R, R)-2$ to $0,0.4,0.8,1.2,1.6,2.0,2.4,3.2$, 3.6, $4.0 \mu \mathrm{M} \mathrm{Zn}^{2+}$ in $60 \%$ acetonitrile/aqueous solution.

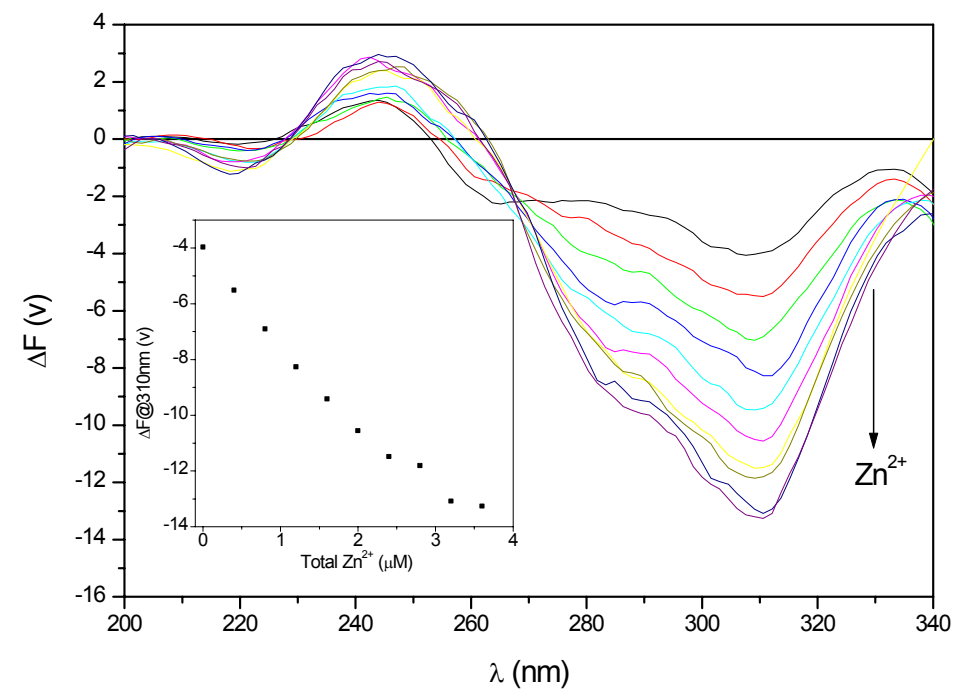

Figure 4d. UV response of $3.2 \mu \mathrm{M}(R, R)-2$ to $0,0.4,0.8,1.2,1.6,2.0,2.4,3.2$, 3.6, $4.0 \mu \mathrm{M} \mathrm{Zn}^{2+}$ in $60 \%$ acetonitrile/aqueous.

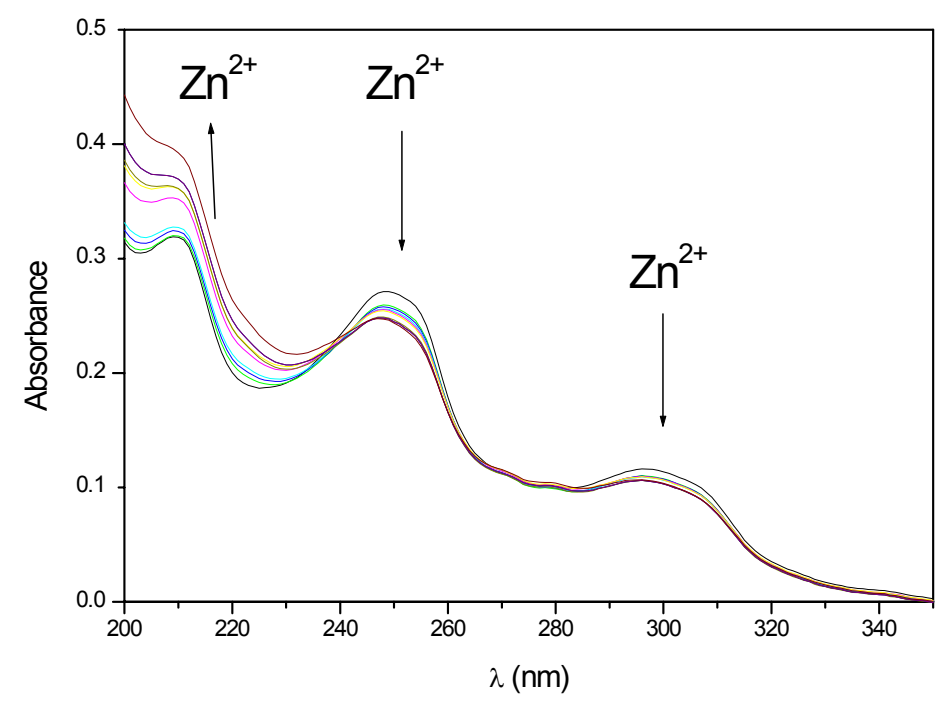


Figure 4e. $\left(\mathrm{F}_{\mathrm{L}}+\mathrm{F}_{\mathrm{R}}\right)$ response of $3.2 \mu \mathrm{M}(R, R)-2$ to $0,0.4,0.8,1.2,1.6,2.0,2.4,3.2$, 3.6, $4.0 \mu \mathrm{M} \mathrm{Zn}^{2+}$ in $60 \%$ acetonitrile/aqueous solution.

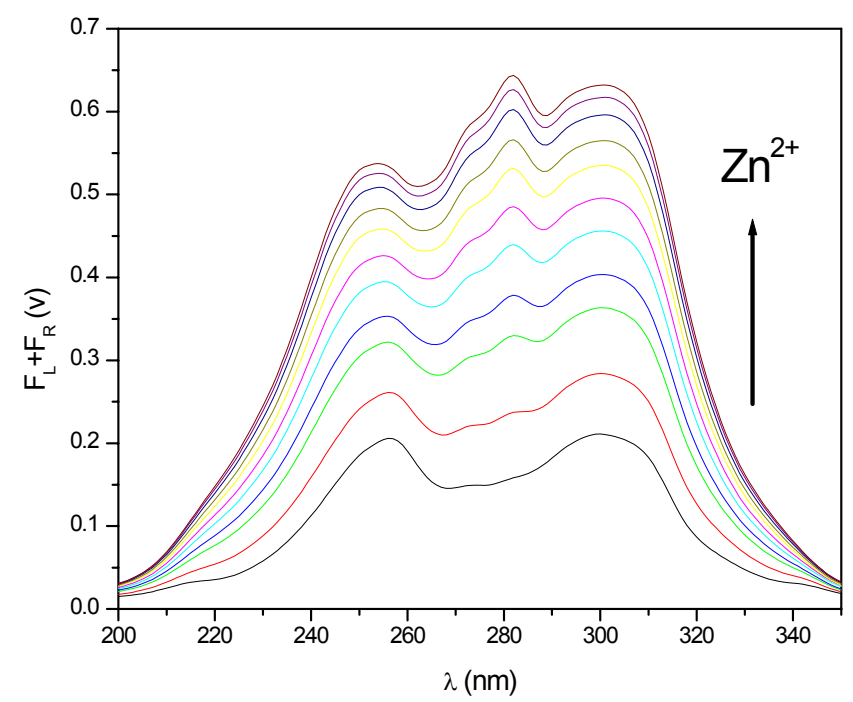

Figure $4 f$. FDCD (converted to $\mathrm{CD}$ ) response of $3.2 \mu \mathrm{M}(R, R)-2$ to $0,0.4,0.8,1.2,1.6$,

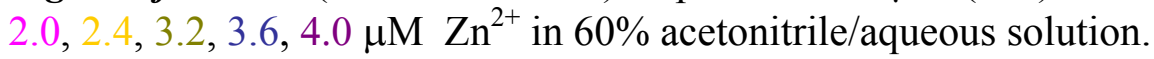

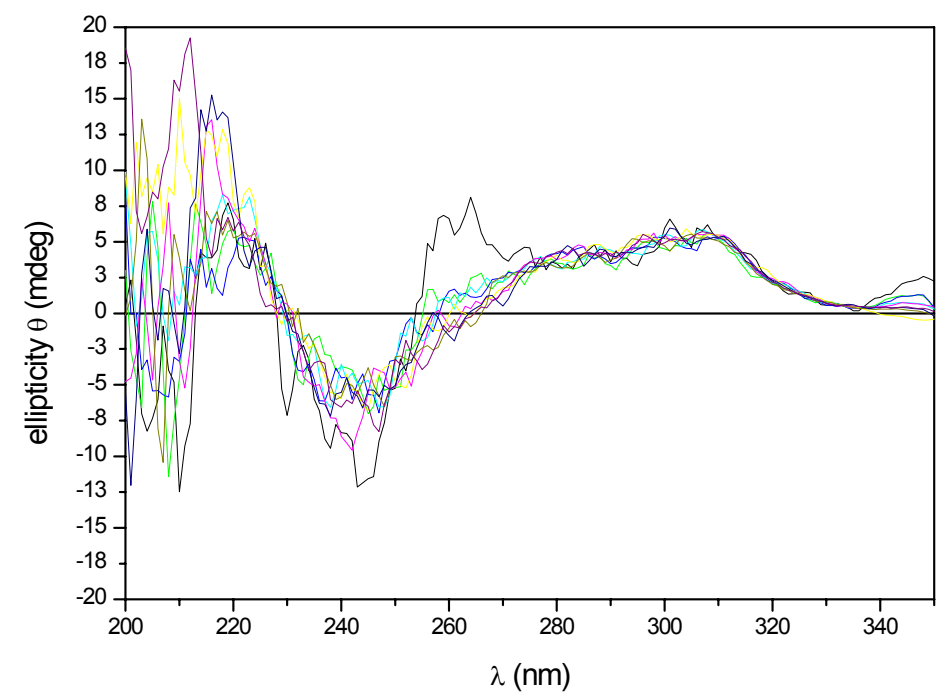


Figure 4g. $\Delta \mathrm{F} / \mathrm{F}$ response of $3.2 \mu \mathrm{M}(R, R)-2$ to $0,0.4,0.8,1.2,1.6,2.0,2.4,3.2$,

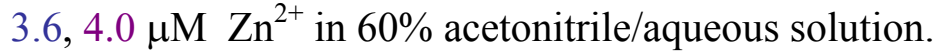

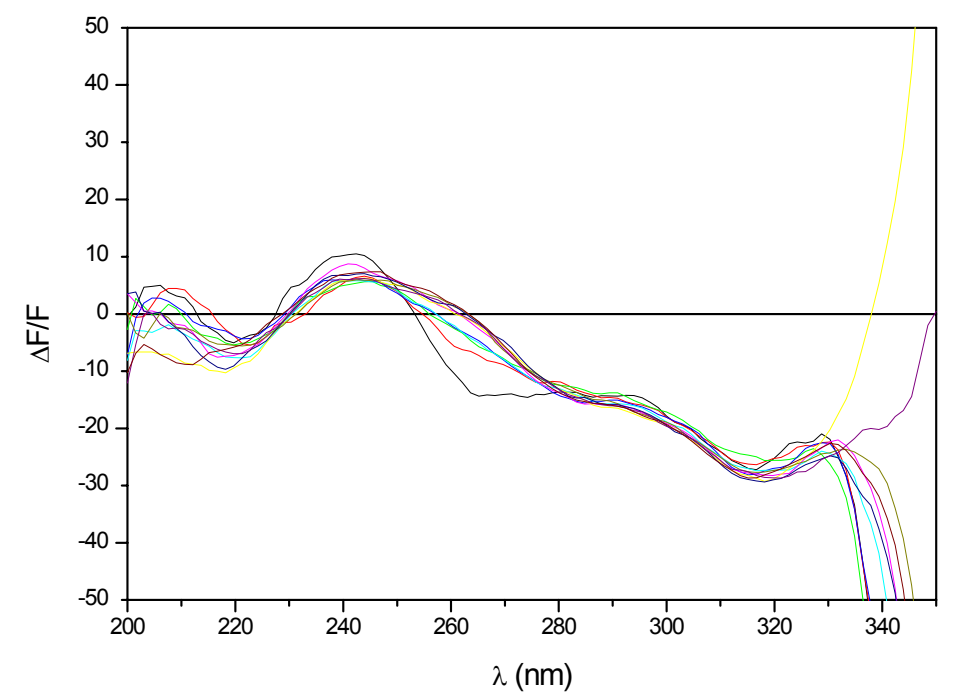




\section{HEW lysozyme responses to $\mathrm{Zn}^{2+}$ in $60 \%$ acetonitrile/aqueous solution.}

Figure 5a. Fluorescence response of $1.0 \mathrm{mg} / \mathrm{mL}$ HEW lysozyme to Zinc in $60 \%$ acetonitrile/aqueous solution. (From top to bottom, the spectrum corresponds to that of lysozyme and the presence of $1 \mu \mathrm{M}, 4 \mu \mathrm{M}, 7 \mu \mathrm{M}, 10 \mu \mathrm{M}$, and $850 \mu \mathrm{M} \mathrm{Zn}^{2+}$. Ex: $280 \mathrm{~nm}$ )

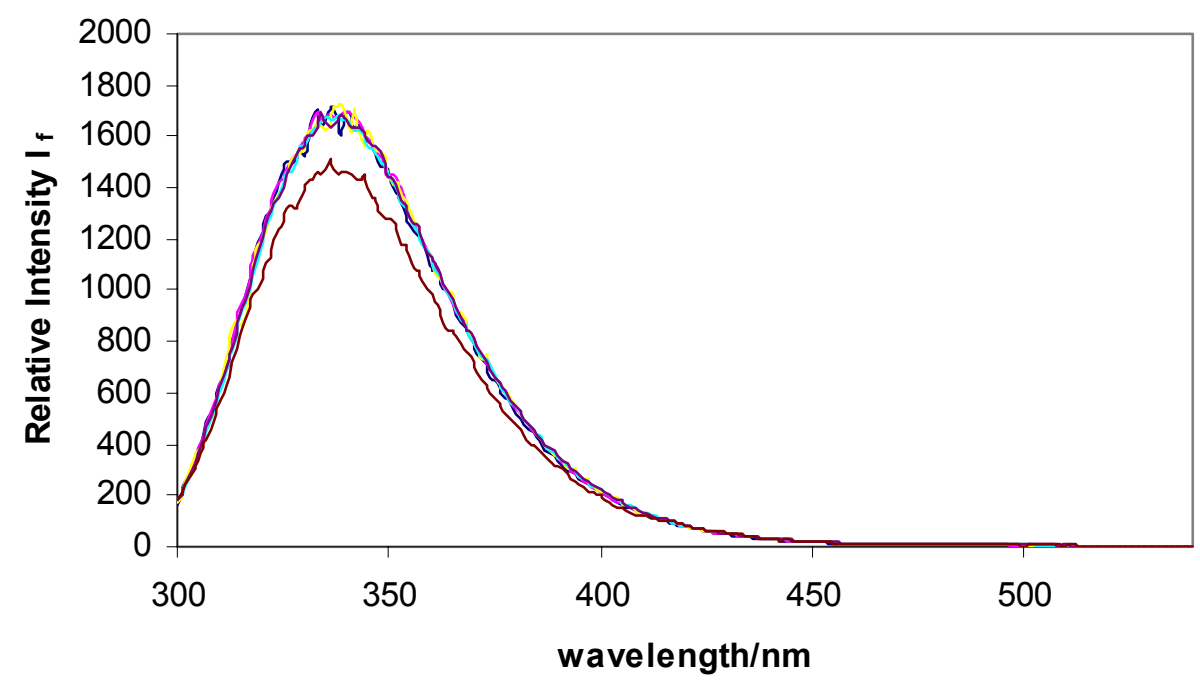

Figure $5 \boldsymbol{b}$. CD response of $1.0 \mathrm{mg} / \mathrm{mL}$ HEW lysozyme to $\mathrm{Zn}^{2+}$ in $60 \%$ acetonitrile/aqueous solution.(From bottom to top at $300 \mathrm{~nm}$, the spectrum corresponds to that of lysozyme and the presence of $1 \mu \mathrm{M}, 4 \mu \mathrm{M}, 7 \mu \mathrm{M}, 10 \mu \mathrm{M}$, and $850 \mu \mathrm{M} \mathrm{Zn}^{2+}$.)

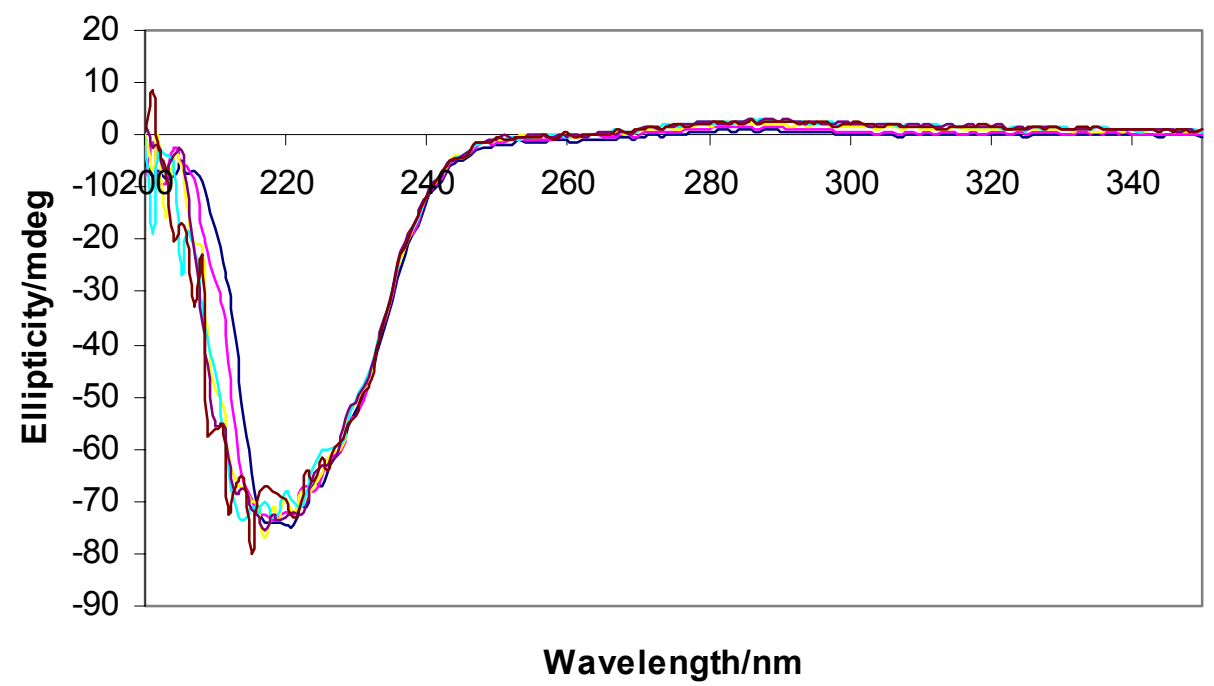


Figure 5c. $\Delta \mathrm{F}$ response of $1.0 \mathrm{mg} / \mathrm{mL} \mathrm{HEW}$ lysozyme to $\mathrm{Zn}^{2+}$ in $60 \%$ acetonitrile/aqueous solution.

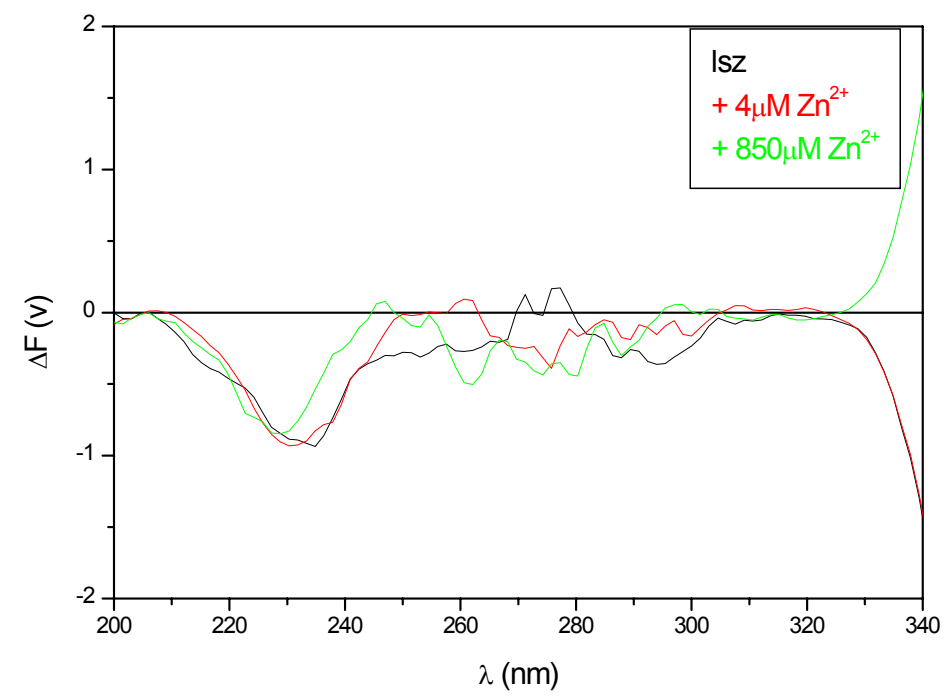


V. Responses of $3.2 \mu \mathrm{M}(R, R)-2$ to $\mathrm{Zn}^{2+}$ in $60 \%$ acetonitrile/aqueous solution at the presence of $1.0 \mathrm{mg} / \mathrm{ml}$ HEW lysozyme.

Figure 6a. UV response of $3.2 \mu \mathrm{M}(R, R)-2$ to $0,0.4,0.8,1.2,1.6,2.0,2.4,3.2,4.0,4.8$ $\mu \mathrm{M} \mathrm{Zn}^{2+}$ in $60 \%$ acetonitrile/aqueous solution at the presence of $1.0 \mathrm{mg} / \mathrm{ml} \mathrm{HEW}$ lysozyme.

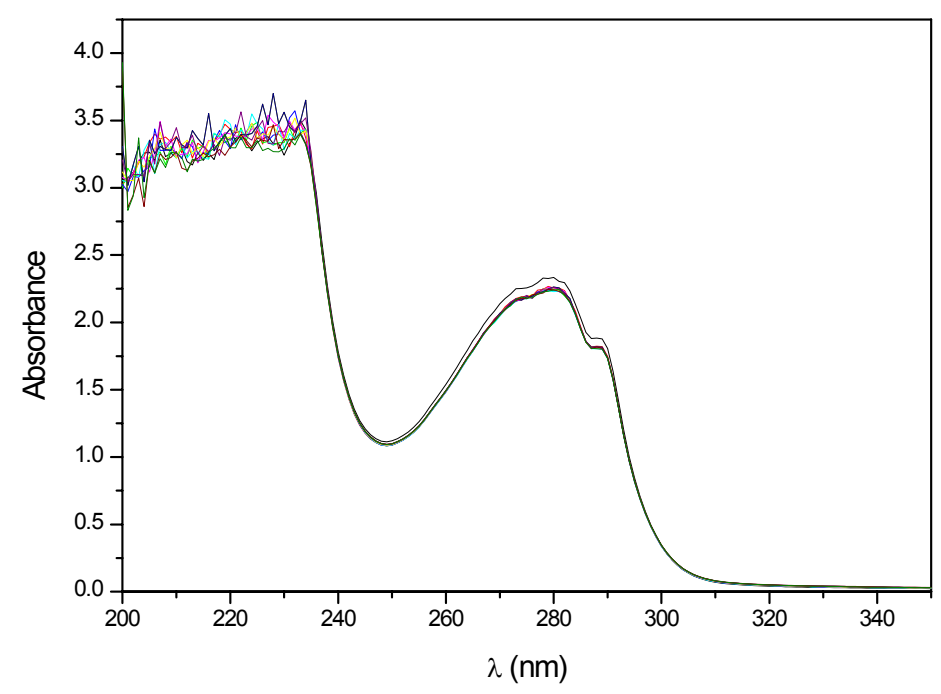

Figure 6 b. $\mathrm{F}_{\mathrm{L}}+\mathrm{F}_{\mathrm{R}}$ response of $3.2 \mu \mathrm{M}(R, R)-2$ to $0,0.4,0.8,1.2,1.6,2.0,2.4,3.2,4.0$, $4.8 \mu \mathrm{M} \mathrm{Zn}^{2+}$ in $60 \%$ acetonitrile/aqueous at the presence of $1.0 \mathrm{mg} / \mathrm{ml} \mathrm{HEW}$ lysozyme.

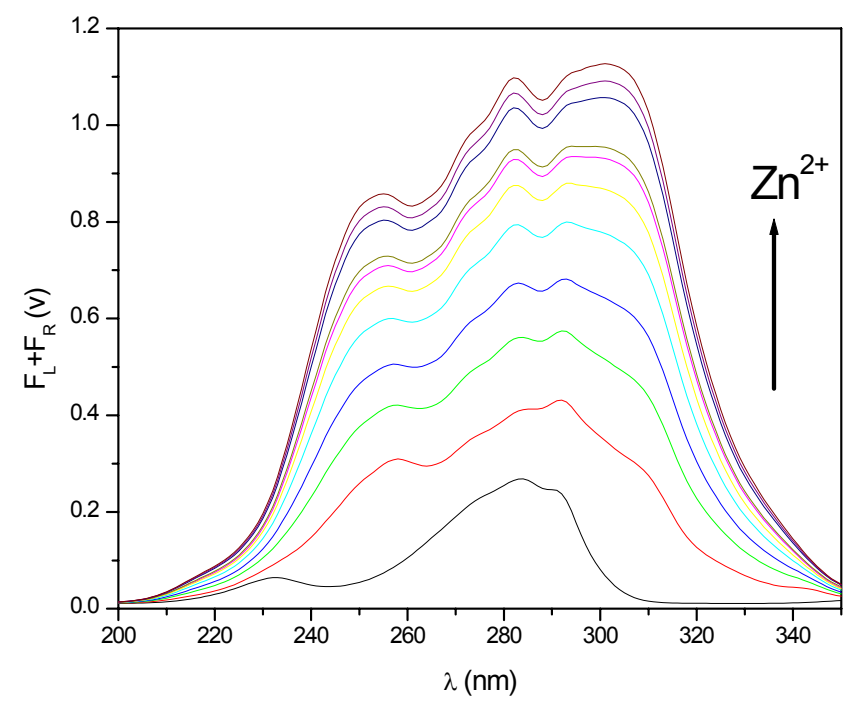


Figure 6c. FDCD (converted to $\mathrm{CD}$ ) response of $3.2 \mu \mathrm{M}(R, R)-\mathbf{2}$ to $0,0.4,0.8,1.2,1.6$, $2.0,2.4,3.2,4.0,4.8 \mu \mathrm{M} \mathrm{Zn}^{2+}$ in $60 \%$ acetonitrile/aqueous solution at the presence of 1.0 $\mathrm{mg} / \mathrm{ml} \mathrm{HEW} \mathrm{lysozyme.}$

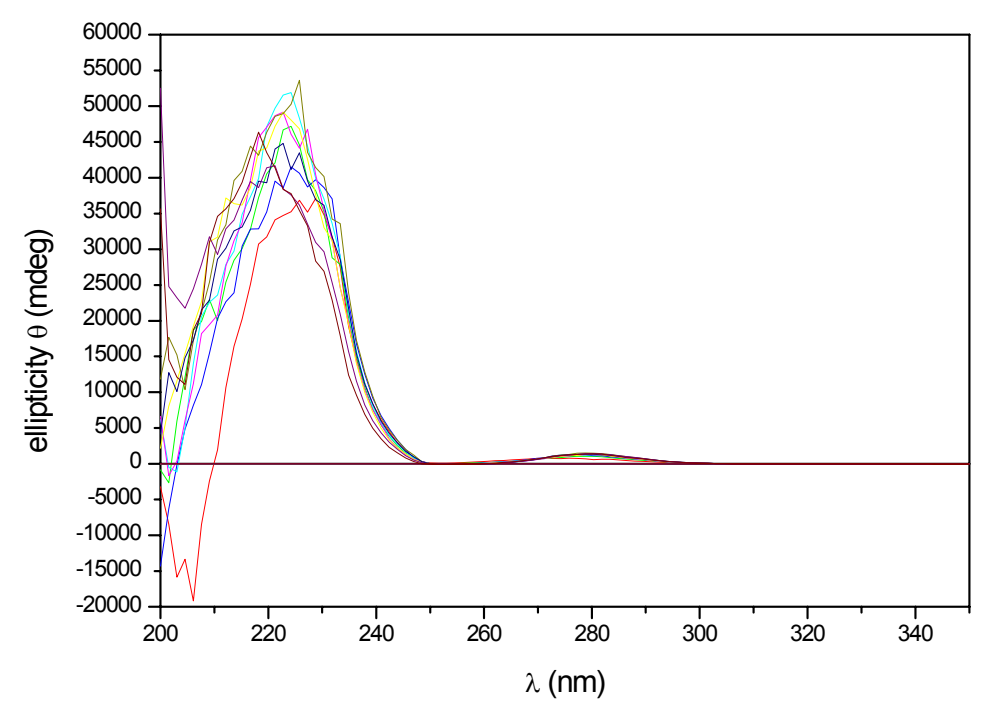

Figure $6 \boldsymbol{d}$. $\Delta \mathrm{F} / \mathrm{F}$ response of $3.2 \mu \mathrm{M}(R, R)-2$ to $0,0.4,0.8,1.2,1.6,2.0,2.4,3.2,4.0,4.8$ $\mu \mathrm{M} \mathrm{Zn}{ }^{2+}$ in $60 \%$ acetonitrile/aqueous solution at the presence of $1.0 \mathrm{mg} / \mathrm{ml} \mathrm{HEW}$ lysozyme.

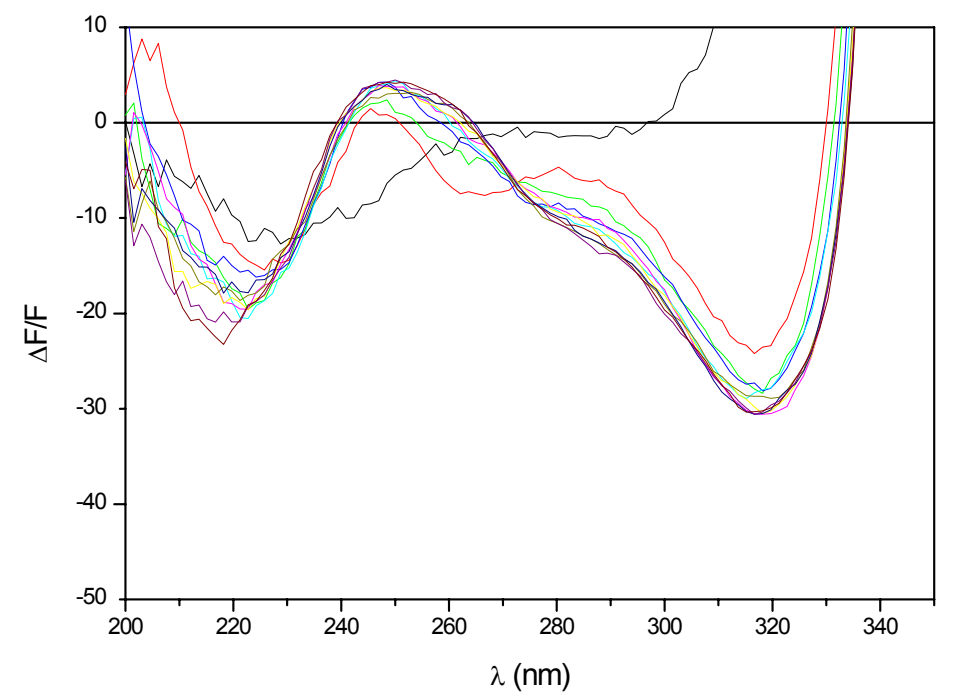




\section{Response of $4 \mu \mathrm{M}(S, S)-2$ to $\mathrm{Cu}^{2+}$ in acetonitrile.}

Figure 7a. Fluorescence response of $4 \mu \mathrm{M}(S, S)-2$ to $\mathrm{Cu}^{2+}$ in acetonitrile (Ex: $\left.280 \mathrm{~nm}\right)$.

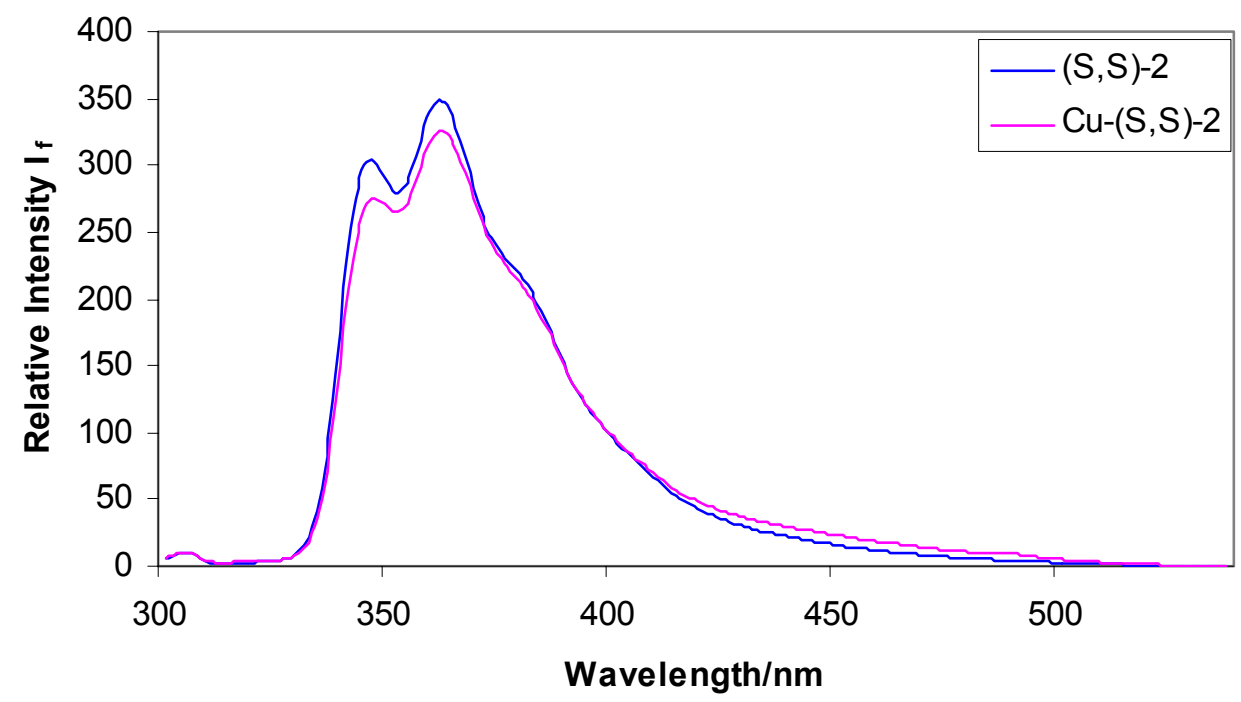

Figure $7 \boldsymbol{b}$. $\mathrm{CD}$ response of $4 \mu \mathrm{M}(S, S)-2$ to $\mathrm{Cu}(\mathrm{II})$ in acetonitrile

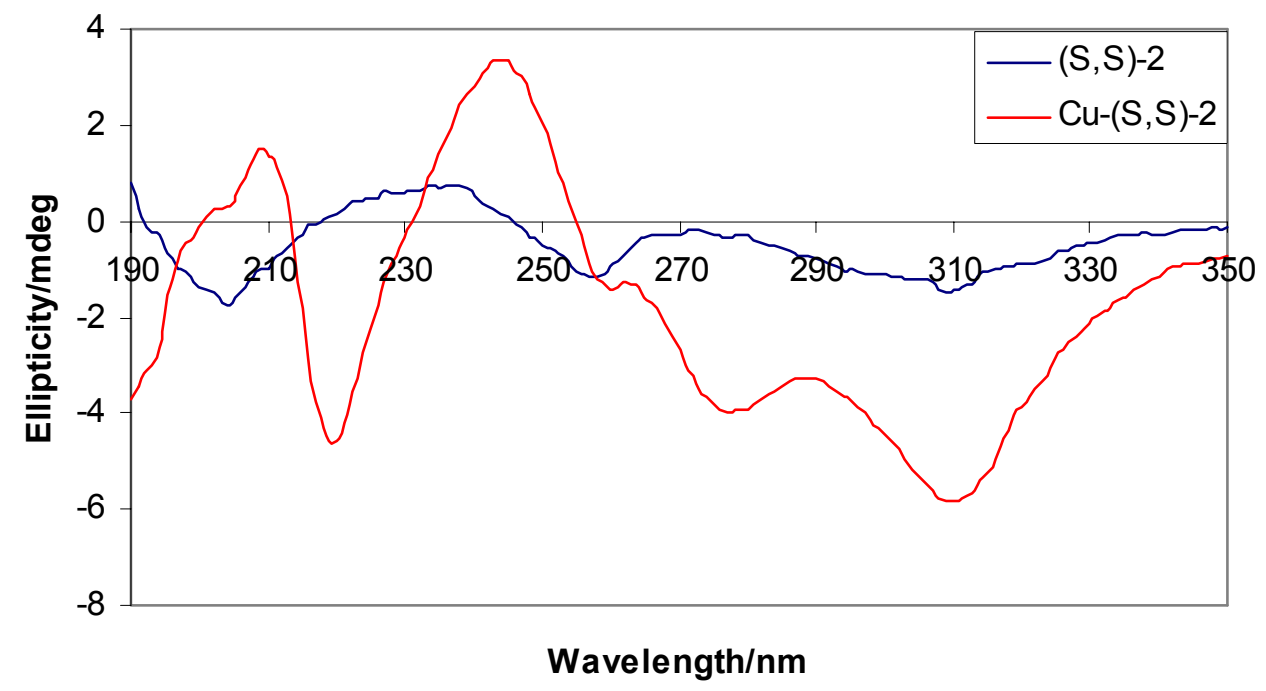


Figure $7 c . \Delta \mathrm{F}$ response of $4 \mu \mathrm{M}(S, S)-2$ to $\mathrm{Cu}^{2+}$ in acetonitrile (Fluorescence filter cutoff: 360nm, 700V, 81 degree).

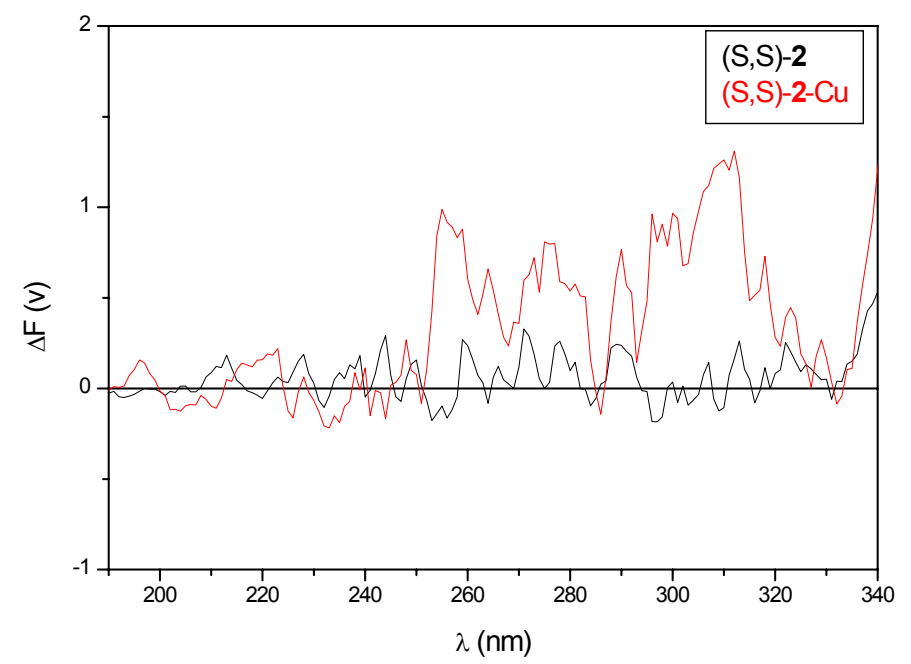




\section{Response of $4.8 \mu \mathrm{M}(R, R)-1$ to $\mathrm{Cu}^{2+}$ in acetonitrile.}

Figure 8a. Fluorescence response of $4.8 \mu \mathrm{M}(R, R)-\mathbf{1}$ to $\mathrm{Cu}^{2+}$ in acetonitrile. (Ex: 280 $\mathrm{nm})$.

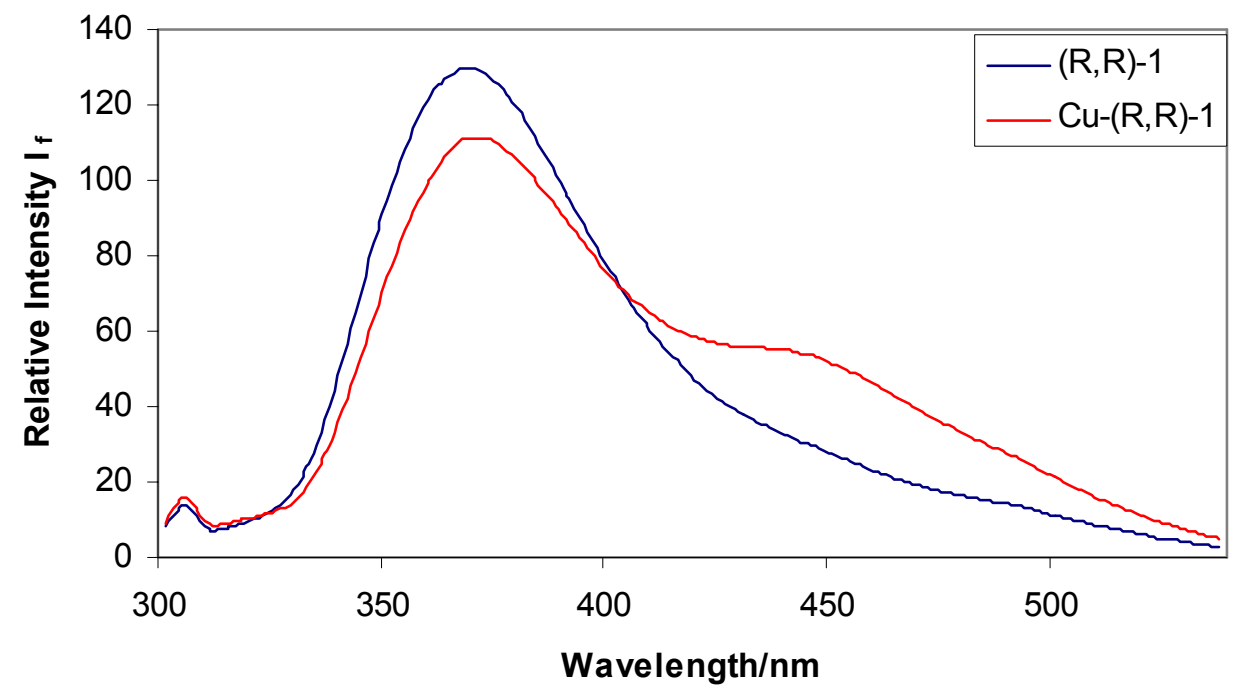

Figure 8b. $\mathrm{CD}$ response of $4.8 \mu \mathrm{M}(R, R)-1$ to $\mathrm{Cu}^{2+}$ in acetonitrile

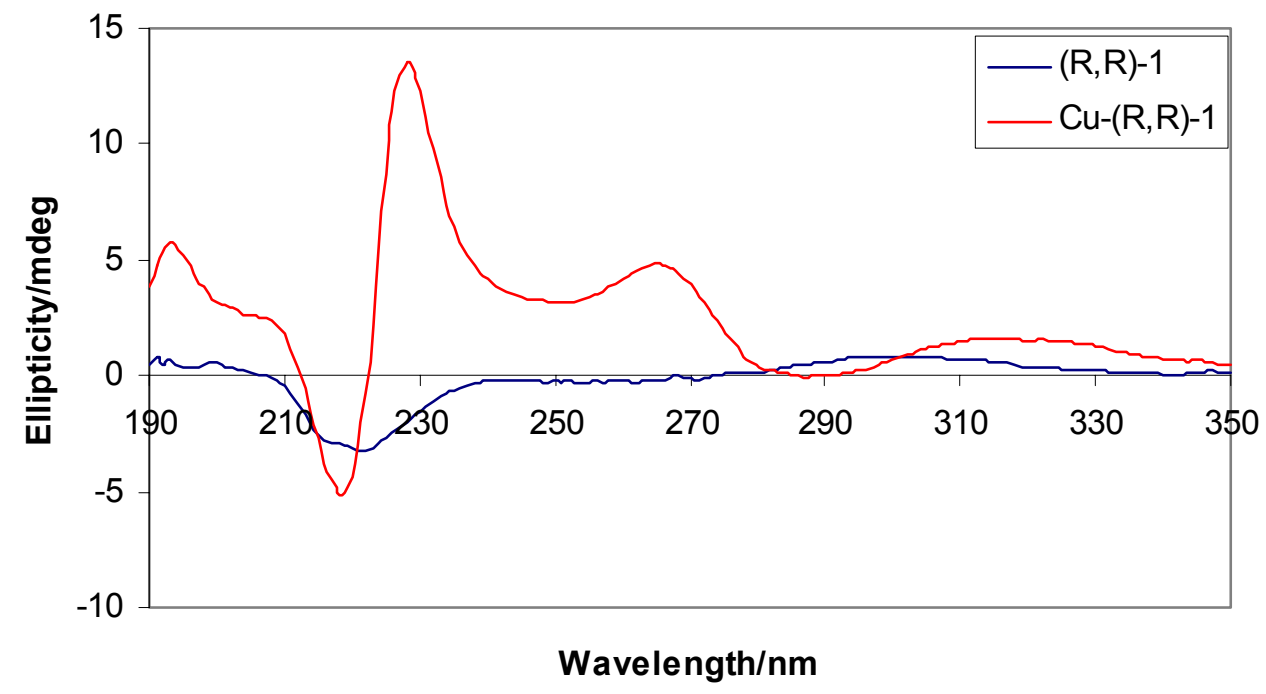


Figure $8 c . \Delta \mathrm{F}$ response of $4.8 \mu \mathrm{M}(R, R)-1$ to $\mathrm{Cu}(\mathrm{II})$ in acetonitrile. (Fluorescence filter cutoff: $360 \mathrm{~nm}, 700 \mathrm{~V}, 81$ degree.)

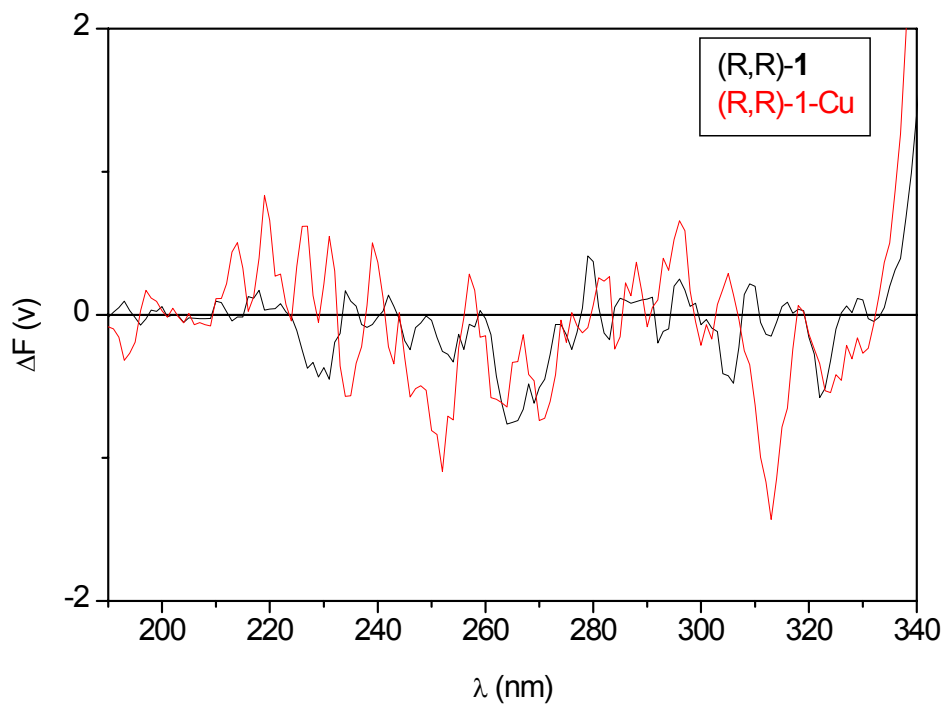

VIII.

Figure 9. $\Delta \mathrm{F}$ response of $5 \mu \mathrm{M}(S, S)-1$ to $\mathrm{Zn}(\mathrm{II})$ and $\mathrm{Cu}(\mathrm{II})$ in acetonitrile (Fluorescence filter cutoff: $360 \mathrm{~nm}, 660 \mathrm{~V}, 81$ degree).

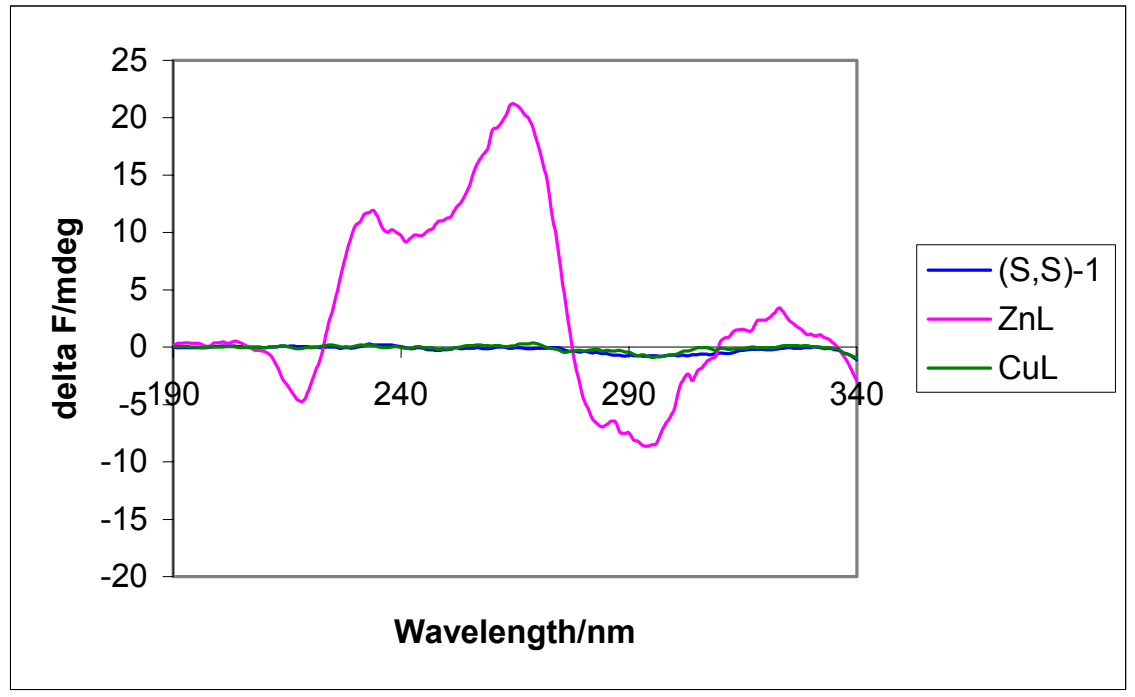

